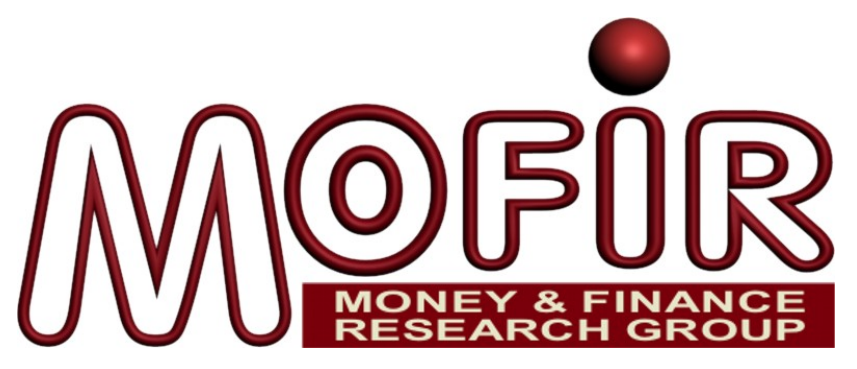

\title{
Does Gender Matter in Bank-Firm RELATIONSHIPS? \\ Evidence from Small Business Lending
}

\author{
ANDrea BellucCi \\ Università di Urbino \\ Alaxander V. Borisov \\ Indiana University \\ Alberto ZaZzaro \\ Università Politecnica delle Marche, Department of Economics \\ $M o F_{I} R$ \\ CFEPSR
}

MoFiR working paper $\mathrm{n}^{\circ} 31$

October 2009 


\title{
DOES GENDER MATTER IN BANK-FIRM RELATIONSHIPS? \\ EVIDENCE FROM SMALL BUSINESS LENDING ${ }^{1}$
}

\author{
ANDREA BELLUCCI \\ UNIVERSITY OF URBINO \\ AleXander V. Borisov \\ INDIANA UNIVERSITY \\ Alberto ZazZaro \\ POLYTECHNIC UNIVERSITY OF MARCHE
}

\begin{abstract}
In this paper we study the relevance of the gender of the contracting parties involved in lending. We show that female entrepreneurs face tighter access to credit, even though they do not pay higher interest rates. The effect is independent of the information available about the borrower and holds if we control for unobservable individual effects. The gender of the loan officer is also important: we find that female officers are more risk-averse or less self-confident than male officers as they tend to restrict credit availability to new, unestablished borrowers more than their male counterparts.
\end{abstract}

JEL Classification: G21; G32; J16

Keywords: Gender-based discrimination, Female-owned enterprises; Loan officers

\footnotetext{
${ }^{1}$ We are grateful to Andrea Presbitero, Giorgio Calcagnini, Alicia Robb, Philip Strahan, John Watson as well as participants at the Annual meeting of the Midwest Finance Association (Chicago) and seminar participants at the University of Urbino and Ancona for their valuable comments.
} 


\section{INTRODUCTION}

Does gender play a role in bank-firm relationships? This question has attracted some attention in the banking literature, broadly limited to the issue of discrimination against female business owners, while leaving the nature of loan officers in the background.

Observed gender-based differences in interest paid, collateral requirements and credit availability can be due to supply-driven discrimination, demand-driven factors, or a combination of both. For example, given the lower diffusion of female-owned businesses in the economy, information on them can be more limited and less reliable, making access to credit at fair prices more difficult for creditworthy female borrowers. As a result of this adverse selection mechanism, the average quality of funded female-owned firms decreases along with the loan officers' beliefs about the average creditworthiness of female applicants, causing a self-reinforcing Arrowian statistical discrimination mechanism (Calem and Stutzer 1995; Scalera and Zazzaro 2001). On the other hand, preferences and cultural beliefs about gender may influence the loan officers' perceptions of the borrower's risk and their decisions on loan applications, causing Beckerian tastebased discrimination. However, observed gender differences in the terms of loan contracts could also stem from differences in "fundamentals" between male- and female-owned enterprises, like human capital, entrepreneurial ability, own-capital availability, sector of operation, economic connections and even gender-based discrimination in other markets.

Recently, a few papers have focused on the lender's gender, to investigate whether perceptions of borrowers' creditworthiness significantly differ between male and female loan officers (Wilson et al. 2007; Ravina 2008) or whether the average default rates on loans handled by female officers are statistically lower (Agarwal and Wang 2008; Beck et al. 2009). Several reasons as to why the lender's gender can influence the bank-firm relationship have been advanced, basically ascribable to risk-attitude and cultural/social factors. First, robust evidence based on both experimental and 
real data, suggests that women generally perceive events as riskier and tend to be more risk-averse and less self-confident than men, especially in the areas of financial decision-making and investments (Powell and Ansic 1997; Byrnes et al. 1999; Barber and Odean 2001; Eckel and Grossman 2008; Croson and Gneezy 2009). Second, sociologists have amply documented the fact that women advance professionally within organizations more slowly than men and are less likely to move to higher positions (Walker and Fennel 1986). At the same time, women are less likely to accept jobs away from their family and therefore have more difficulty in advancing in their careers by moving to other enterprises (Beck et al. 2009). For such reasons, female loan officers could be inclined to use stricter criteria when deciding upon loan applications in order to avoid defaults, generate fewer losses for the bank and maximize the probability of internal career advancement.

On the other hand, women are usually found to be less sensitive to competitive incentives than men (Gneezy, Niederle and Rustichini 2003; Croson and Gneezy 2009). Other studies have also stressed that women tend to be less selfish and exhibit greater cooperative behavior driven by a sort of "morality of responsibility" (Gilligan 1982). According to this view, by showing sympathy with others' interests (in our context, borrowers), women might be willing to relax the search for their own goals (e.g., the reaching of performance objectives assigned by the bank to its loan officers). If the latter attitude prevails, we should expect female officers to approve more credit at easier terms.

Besides the separate effects of gender on either side of the lending transaction, the particular gender pairing could also have an impact on the lending decision. For example, a number of studies have established that people's behavior varies with the sex of the other party involved in the transaction. For example, Eckel and Grossman (2001) refer to the effects of "chivalry" and "solidarity" to explain why in an ultimatum game the rate of acceptance by both males and females is higher when the proponent is a female. Similar results have been obtained by Dufwenberg and Muren (2006), while Gupta et al. (2005) show experimental evidence that men compete more 
aggressively against male competitors than against female ones. In contrast, Ben-Ner et al. (2004) document the existence of a gender-based envy which induces women to donate less to other women than to male recipients or recipients of unknown gender.

In this paper we analyze the importance of gender by looking at both sides of the lending transaction. We use a unique proprietary dataset which includes information on contract terms, loan relationships, borrower and lending office characteristics of all credit lines extended by a major Italian regional bank to individually-owned firms (i.e. sole proprietorships) in two provinces in 2004 and 2006. First, we explore whether female-owned businesses pay higher interest rates, pledge collateral more often, or face stricter credit limits than male-owned businesses. Second, we assess whether interest rates, collateral and credit constraints vary systematically with the proportion of female loan officers at the lending branch. Although we do not have information on the gender of the loan officer who handles the loan application, we can prove the robustness of our results on the subsample of loans that originate from branches where all loan officers are either males or females.

By way of preview, we find that female-owned businesses are not discriminated against in the pricing terms of their loan contracts, while they are disadvantaged vis-à-vis their male counterparts in terms of collateral requirements and credit availability. These findings are independent of the time elapsing from the beginning of the lending relationship with the bank and are confirmed once we control for individual effects, suggesting that gender-based discrimination in credit markets is, at least partly, driven by the loan officer's taste.

Moving on to the effect of the loan officer's gender, we find that on average the presence of female loan officers at the lending branch does not have significant effects on price and non-price terms of loan contracts. However, consistent with the hypothesis of lower risk propensity on the part of women, we find that the likelihood that new borrowers are credit constrained is significantly higher at branches with a large share of female officers. However, the gender of the loan officer 
loses its importance as the lending relationship with the borrower proceeds. Furthermore, when we distinguish between male and female borrowers, we find that the presence of female loan officers is associated with lower collateral requirements when the borrowers are women and with lower interest rates when the borrowers are men. Importantly, our findings are broadly confirmed when we focus on loans granted at branches populated by only male or only female bank officers.

The rest of the paper is organized as follows. In the next section, we briefly discuss the related literature on the borrower's and lender's gender. In Section 3, we describe the dataset and the variables used in this study along with the institutional and economic background. In Section 4, we present the empirical strategy and methodological issues, while in Section 5 we discuss our regression results. We conclude in Section 6.

\section{RELATED LITERATURE}

\subsection{Gender-based discrimination}

An oft-mentioned concern in policy debates and the popular press is the existence of gender-based discrimination in credit markets which does not allow female-owned small enterprises to fund their investments and to operate on an efficient scale. However, the empirical evidence is mixed and, above all, has not been able to identify the source of the observed differences in access to finance between males and females.

Using the National Survey of Small Business Finance (NSSBF) for the U.S., Cavalluzzo and Cavalluzzo (1998) study the impact of borrower's gender on the probability of loan approval and on the interest rate charged on granted loans. Controlling for borrower's race and a large set of firm and loan characteristics, they show that female small business owners are not disadvantaged vis-àvis their male counterparts since their loan applications are almost equally likely to be approved and the interest rates charged on their loans are comparable to those charged on loans granted to male 
borrowers. The authors even show that in highly concentrated credit markets, female borrowers tend to be treated preferentially by the lenders. However, in contrast to their earlier findings, in a subsequent study Cavalluzzo et al. (2002) provide some support for the existence of gender-based discrimination in concentrated markets. As a result, the authors cannot unambiguously conclude whether or not the U.S. credit markets are beset by gender-based discrimination. Along the same lines of research, by studying both loan application denials and interest rates, Blanchflower et al. (2003) fail to establish the existence of gender-based discrimination in U.S. credit markets after accounting for the borrower's past credit history and other risk characteristics. Coleman (2000) finds that creditors do not seem to discriminate against women with regard to credit availability, but rather on the price and non-price terms of the loan contract. In particular, females are more likely to be asked to pledge collateral and pay higher interest rates. Using the same data sources, Robb and Wolken (2002) confirm the stylized fact that male small business owners are significantly more likely to have an outstanding loan or to have applied for a loan (i.e. not fearing denial) than female owners. However, as the authors suggest, this observation might be driven by differential inherent borrower characteristics and preferences rather than by gender-based discrimination. Controlling for various confounding factors, they show that female borrowers are not treated systematically differently from their male counterparts. Similarly, Cole and Mehran (2009) report that once controlled for firm and owner characteristics, female entrepreneurs are neither significantly more discouraged from applying for credit nor more likely to be denied credit when they apply.

The international evidence depicts a rather different picture from that of the U.S. credit market. Muravyev et al. (2009) use the Business Environment and Enterprise Performance Survey (BEEPS) to study gender-based discrimination in small business lending in 26 transition economies from Central and Eastern Europe and several industrialized nations from Western Europe. The authors provide evidence in which female-owned businesses are significantly less likely to receive a loan 
and pay on average higher interest rates compared to their male counterparts. Similarly, Alesina et al. (2008) analyze the role of borrower's gender in the market for small business credit in Italy. Their study concludes that women typically pay higher interest rates than men even after controlling for the competitive structure of the lending market and various borrower risk characteristics. Moreover, they show that the impact of gender-based discrimination extends even beyond the borrower per se as a female borrower guaranteed by a female guarantor is associated with the most expensive credit $^{2}$.

\subsection{Lender's gender}

Recently, a new stream of literature has shifted the focus to the role of the economic agents who are called to decide upon loan approvals and to the way in which their personality, experience, beliefs and perceptions shape the credit relationship (Anderson 2004; Uchida et al. 2006; Hertzberg et al. 2009). Within this area of research, a number of studies have focused on the gender of the decision maker (individual lender or loan officer) as one of the major factors influencing the outcome of the lending transaction.

Using the results of a survey of 36 loan officers employed by a big British bank, Carter et al. (2007) show that although both female and male loan officers use similar assessment criteria for approving loan applications, there are gender-based differences in the relative importance attached by the loan officers to some of these criteria. For example, female loan officers tend to focus on procedural and business elements of the loan application, while male loan officers rely more heavily on individual decision making and negotiation. However, the authors find no evidence to support the notion that when evaluating male and female loan applicants, male loan officers use different criteria from those of female loan officers.

\footnotetext{
${ }^{2}$ However, other recent studies on the Italian experience find no evidence of gender-based discrimination in access to credit (Favaretto 2007; Calcagnini et al. 2008).
} 
In a related paper, Ravina (2008) considers individuals granting and receiving internet loans via a specialized web-site (Prosper) to assess whether the lender's preferences and perceptions play a role in a virtual lending process. She documents that despite being uncorrelated with performance or credit risk, observable characteristics of the borrower such as attractiveness and personal presentation have a strong impact on the outcome and terms of the loan-granting transaction. Moreover, she ascertains that the presence of more than one lender of the same gender as the borrower increases the probability that the loan is funded but does not influence the terms of the loan contract.

Alesina et al. (2008) consider the lending practices of Italian banks which have female directors on their boards. On average, borrowers dealing with such banks pay significantly lower interest rates and this favorable effect holds for both male and female borrowers.

Finally, Beck et al. (2009) study the default probability of loans granted by a microcredit bank in Albania in the period 1996-2006. They show that the default rates on loans handled by female loan officers are significantly lower than those on loans decided by male officers, regardless of the experience accumulated on the job.

\section{DATA AND VARIABLES}

\subsection{Dataset}

This study utilizes a unique proprietary dataset that consists of more than 7,800 credit lines made available to individually-owned small businesses (i.e. sole proprietorships) by a major Italian bank belonging to a large Italian banking group quoted on the Milan Stock Exchange (hereafter, for the sake of confidentiality, simply the bank). The sample includes the entire bank portfolio of existing credit lines as of September 2004 and 2006 in two Italian provinces which, according to Chamber of Commerce (UnionCamere) data, have some of the largest concentrations of individually-owned 
firms and SMEs. Consistently, one of the bank's core businesses is provision of financing and credit to SMEs. In the years we consider, the bank lent to individually-owned firms operating in 23 different sectors of the economy within a total area of approximately $4,800 \mathrm{~km}^{2}$.

The dataset made available by the bank includes information on loan contract terms (e.g. credit limit, interest rate, amount of collateral), borrower characteristics (e.g. sales, gender of the owner, industry specialization), aspects of the bank-borrower relationship (e.g. length of the relationship, whether or not the borrower uses other services provided by the bank, exclusivity of the relationship) and characteristics of the lending branch (e.g. geographic location, total number of loan officers, number of female loan officers). To this dataset, we add information on the distance between each borrower and the lending branch, the distance between borrowers and rival banks, the distance between the lending branch and bank headquarters and the concentration of the local credit market.

Our analysis comprises only loan contracts with a credit limit up to $€ 300,000$ since the bank's lending policy stipulates that contracts above this limit must be approved at its headquarters. In such cases, the importance of the gender of the local loan officer is blurred due to the main decision-making process being located elsewhere.

Table 1 provides summary statistics for the variables used in our analysis. Definitions and construction of the variables are described in the next section and summarized in the Appendix. The first column (All firms) shows the mean of each variable, followed by its standard deviation in parentheses. The second (Male owner) and third (Female owner) columns are structured in a similar way but segregate the sample based on borrower's gender. The last column (Means differences) provides the p-values of statistical tests for equality between the means of each variable across the two sub-samples of female- and male-owned enterprises.

[INSERT TABLE 1 HERE] 


\subsection{Dependent variables}

We analyze the role of gender on price and non-price terms of the loan contract. In particular we construct three dependent variables: Interest rate, Collateral and Credit availability. The first dependent variable is the interest rate actually paid by the borrower for the utilized amount of credit, the average rate being 7.10 percent. The difference in the interest rate between female and male borrowers is small and not statistically significant: female borrowers pay on average approximately 10 basis points more than male borrowers (7.173 vs. 7.076$)$.

The second variable of interest is Collateral. It is an indicator variable assuming the value of 1 if the credit line is secured by real collateral and 0 otherwise. On average, almost 35 percent of our borrowers are required to pledge real collateral. This share increases to 38 percent if we consider female borrowers, while for males it decreases to 34 percent.

Finally, the third dependent variable is Credit availability, a dichotomous variable taking the value of 1 if a borrower draws more credit than what is actually granted by bank in the loan contract and 0 if he/she exhausts or uses strictly less than the available credit line. In Italy, credit lines provide borrowers with a certain degree of flexible use by either allowing them to not fully utilize the committed credit, free of any charge, or overdraw up to a certain amount, subject to fees and penalty interest rates on the overdrawn. For overdrawing firms, the access to credit may be said to be tighter in the sense that they may count on a lower credit buffer. On average, 37.5 percent of the borrowers face tight credit limits. Furthermore, the frequency with which female small business owners overdraw is significantly higher than that experienced by male owners (45.9 and 35.1 percent, respectively) ${ }^{3}$.

\footnotetext{
${ }^{3}$ In the multivariate analysis, we also used a refinement of the variable Credit availability: we constructed an ordinal variable which takes the value of 0 if the borrowers use the credit line up to an amount strictly less than the limit
} 


\subsection{Gender variables}

We build three different gender variables. First, Female owner accounts for the borrower's gender and takes the value of 1 if the small business owner is female and 0 if male. In our sample, approximately $23 \%$ of the firms are female-owned. It is worth noting that this proportion is comparable to that of $18 \%$ documented by Alesina et al. (2008) on a much larger scale and is consistent with the lower diffusion of female-owned firms in the Italian economy.

With respect to the loan officer's gender, we only have information on the number of females in each branch who can decide on a loan application but we do not know whether the loan was actually decided upon and monitored by a male or female loan officer. Therefore, we employ two different branch-specific gender variables. First, we use the percentage of female loan officers with decision-making power at the lending branch (Female_loan_officers). Assuming that loan applications are distributed randomly among loan officers, this variable can be interpreted as the probability that the credit line is approved and serviced by a female loan officer. However, we must recognize that our proxy is bank-branch specific rather than loan-contract specific. Therefore, to gain more precise insights into the impact of the loan officer's gender on the lending relationship, we restrict our analysis to credit lines granted by branches with only male or only female loan officers (mono-gender branches). In this case, we build an indicator variable, Only female loan officers, which takes the value of 1 if the loan was approved at a branch where all loan officers are females and 0 if the lending branch is populated only by male loan officers. From Table 1, we can see that 28.7 percent of all loan officers are females, while almost 8 percent of the bank's branches are populated only by female loan officers.

stipulated in the contract, 1 if they exhaust the credit line, and 2 if they exceed the amount granted by the bank. The results are virtually the same and are not reported in the tables. 


\subsection{Control variables}

In order to find out the effects of gender on the loan contract, we control for a large number of factors concerning borrower characteristics, customer relationships, branch characteristics and market competition.

First, we consider firm size as measured by total sales in the previous year. In particular, we create a step variable, Firm size, which takes the value of 1 if total sales are less than $€ 250,000,2$ if sales range between $€ 250,000$ and $€ 1,500,000$ and 3 if they exceed $€ 1,500,000$. The expected impact of Firm size is to improve firms' access to credit by lowering the interest rate, collateral requirements and the likelihood of experiencing credit tightness. Among the firms in our sample, 81.4 percent are in the first size category, while only 3.5 percent are in the third. On average, female-owned firms are significantly smaller than the male-owned firms.

Second, the extant literature suggests that relational lending is a major factor affecting (positively or negatively) the access to credit of small businesses (Boot 2000). Relational lending technology relies primarily on soft information generated through extended and exclusive contacts between the borrower and the bank through the offering of multiple financial services. The effect of close bank-firm ties on lending terms is in principle ambiguous, as they allow banks to gain extra information on borrowers while simultaneously acquiring monopoly power.

We build three variables, Relationship length, Multiple lending and Other services, each capturing different dimensions of relational lending. Relationship length is the number of days since the firm first borrowed from our bank. On average, the firms included in our sample have been clients of the bank for 3,057 days. The length of the relationship becomes 3,226 and 2,459 days if the owner is male and female, respectively. These figures are comparable to previous findings reported by Cole (1998) and Degryse and Van Cayseele (2000) showing that the average length of the bank-borrower relationship is between 7 and 8 years. For Italy, Gambini and Zazzaro (2009) 
document that firms with fewer than 50 employees maintain credit relationships with their main bank for 12 years on average. In the subsequent multivariate analysis, we take a logarithmic transformation of this variable and express Relationship length as 1 plus the number of days since the firm first borrowed from our bank.

The second metric, Multiple lending, designed to capture the nature of the bank-borrower relationship is a dichotomous variable that takes the value of 1 if the firm borrows from multiple banks and 0 if the borrower has an exclusive relationship with our bank. In our sample, only $3.2 \%$ of the firms have an exclusive relationship with our bank. This percentage does not statistically differ for male- and female-owned firms. Such extensive use of multiple lending is well documented by other studies on Italian firms (D'Auria et al. 1999; Detragiache et al. 2002; Alessandrini et al. 2009) and is consistent with the predictions of Carletti et al. (2007) that more opaque firms are significantly more likely to rely on multi-bank lending.

The third relationship variable, Other services, is another dummy variable that takes the value of 1 if the firm uses additional services provided by the bank and 0 otherwise. The scope of the relationship allows banks to accumulate extra information, enhancing their ability to assess and monitor customers. Only $10 \%$ of the firms in our sample simply borrow from the bank without using additional services, and male borrowers are significantly more likely to rely on other services provided by the bank.

A third set of variables concerns distance and competition. First of all, following a growing body of research (Petersen and Rajan 2000; Berger et al. 2005; Degryse and Ongena 2005; Agarwal and Hauswald 2008; DeYoung et al. 2008), we consider the physical distance that separates firms from the lending branches (Branch-firm distance). More precisely, we take the logarithm of the 
kilometric distance between the firm and the bank's lending branch ${ }^{4}$. In principle, the impact of Branch-firm distance on loan terms is ambiguous, depending on whether cost or competition effects linked to information and transportation costs prevail. Secondly, we consider two measures of competition in the local credit market, which is identified by the postal code of the borrower. First, motivated by previous studies (Degryse and Ongena 2005), we consider the distance between the borrower and the bank's rivals, Rivals-firm distance, as measured by the $25^{\text {th }}$ percentile of all distances between the firm and the branches of other banks in the borrower's local credit market. Second, a branch-based Herfindahl-Hirschman index (HHI) is calculated for September 2004 and 2006 in order to capture the concentration of the local credit market.

The univariate results reported in Table 1 show that the average borrower is located 4.66 kilometers (2.89 miles) away from the lending branch and 3.4 kilometers (2.12 miles) from the bank's rivals in the local credit market. The median distances between firm and bank and between firm and rival branches are 2.14 (1.33) and 1.72 (1.07) kilometers (miles), respectively ${ }^{5}$. On average, male entrepreneurs borrow at a significantly longer distance than females (4.81 vs. 4.14 kilometers), are located further away from the bank's rivals (3.58 vs. 2.84 kilometers) and operate in more concentrated credit markets.

In order to control for branch characteristics, in the discrimination analysis, we include a set of dummy variables for each branch. However, as our loan-officer gender variables are branchspecific and do not change in the sample period, it is not possible to include branch fixed effect in the loan officer analysis. Therefore, in this case, we add a number of variables capturing important

\footnotetext{
${ }^{4}$ All distances are calculated with Routemate, This is professional software designed for calculation of distances and optimization of transportation costs. We use the shortest road and the fastest road as criteria to determine the distance between a firm and a bank branch. Further information is available at the following web page: http://www.nemsys.it/en/prodotti.asp?cod=1 .

${ }^{5}$ These figures are comparable with the distances reported in studies for other countries. For example, using the Survey of Small Business Finances, Brevoort and Wolken (2009) show that in the U.S. the median distance between firm's headquarters and the lender was 5.56 kilometers (3 miles) in 2003 and 7.41 kilometers (4 miles) in 1993. Conducting single-bank studies in Belgium and Sweden, Degryse and Ongena (2005), and Carling and Lundberg (2005) document that the median lender-borrower distance is 2.25 and 2.54 kilometers respectively.
} 
branch characteristics concerning location and organization. With regard to the former aspect, we include a dummy variable that takes the value of 1 if the branch is located in an industrial district area $(\text { District branch })^{6}$. The idea is that branches which are part of an industrial district can benefit from the traditional network economies that characterize this form of spatial organization of businesses and can exploit the advantages of contextual knowledge to make credit access for district firms easier (Alessandrini and Zazzaro 2009). Moreover, we build a variable Branch population which measures the number of people (in thousands) living in the credit market served by the branch.

With regard to bank organization, we include two variables. First, we include the distance between the lending branches and the bank headquarters (Branch-headquarters distance). As suggested by Alessandrini et al. (2009), to the extent that information on local borrowers is soft, available to local loan officers and only vaguely transmissible to the upper layers of the bank, incentive and agency problems increase with the distance between the lending branch and the bank headquarters, thus worsening access to credit for soft-information borrowers.

In a similar vein, we account for the hierarchical level of the lending branch in the organizational structure of the bank. The network of branches of our bank is distributed across several local credit markets and coordinated by the regional headquarters of the bank. Although each bank branch has decision-making power with respect to the credit lines extended by its loan officers, the regional headquarters of the bank can have a greater ability to offer additional services or more efficient communication modes and monitoring skills. We therefore build a dummy variable, Main office, that takes the value of 1 if firms borrow from one of the local headquarters of the bank and 0 if they borrow from local branches (given their size, no loans in our sample are decided upon at the bank headquarter level).

\footnotetext{
${ }^{6}$ We identify industrial district areas using the official classification provided by State Law (317/91) and Regional Law (no. 255, 17 March 1995).
} 
Finally, each regression includes a time dummy and a set of industry dummies built by using the ISTAT (National Institute of Statistics) classification at the two-digit level.

\section{EMPIRICAL STRATEGY}

\subsection{Loan applicant's gender}

In the first part of our analysis, we study whether the gender of the borrower has influence on the loan contract and whether females are discriminated against in the credit market. More precisely, we estimate three models: (i) an OLS model for the interest rate charged by the bank; ii) a Probit model for the likelihood of the bank requiring real collateral; (iii) a Probit model for the likelihood of borrowers drawing more credit than that made available by the bank.

Tighter contract terms on loans to female-owned enterprises would be consistent with discrimination, but they could also indicate that female borrowers are, on average, less creditworthy as their entrepreneurial skills are lower. Furthermore, discrimination itself could be due to radically different mechanisms: it could depend on the loan officers' beliefs or on their preferences. In the former case, discrimination would be due to insufficient information on the quality of female enterprises (statistical discrimination), while in the latter it would be due to the taste of the loan officer called to decide on the loan application (taste discrimination).

In an attempt to identify the nature of the discrimination, if any, we include in the regression model an interaction term between the gender of the borrower and the length of the bank-borrower relationship, Female_owner $\times$ Relationship_length. The idea is that as the length of the bankborrower relationship increases, the lender accumulates more information about the nature of the borrower's business, their payment behavior, creditworthiness, etc. Therefore, a statistically significant coefficient on the interaction term with a sign opposite to that of the coefficient on the gender of the borrower would suggest that as more information is accumulated, the importance of 
the borrower's gender is attenuated. Since the statistical gender-based discrimination is a manifestation of information-related frictions, such a combination of coefficients would support this type of discrimination. On the other hand, if the coefficient on the interaction term is statistically insignificant and the negative effect of the female gender is preserved regardless of the amount of available information to loan officers, we cannot exclude the existence of taste-based discrimination.

Unfortunately, our data set does not have any information on loan performance and we cannot even exclude that stricter contract terms to female-owned firms reflect economic fundamentals of these enterprises rather than loan officer preferences. In order to distinguish between fundamental and discrimination motives for stricter access to credit we exploit the longitudinal dimen sion of our data set. Obviously, given that our variable of interest, Female owner, is time-invariant we cannot use the Within estimator, but we estimate random effect models. As the unobserved factor might not be orthogonal to other regressors, we also apply the 2SLS estimator proposed by Hausman and Taylor (1981). In this procedure, some explanatory variables are allowed to be correlated with the individual effects and instrumented with the exogenous regressors, the average across time of the exogenous time-variant regressors and the difference between the endogenous time-variant variable and its individual average.

\subsection{Loan officer gender}

In the second part of our analysis we augment the three discrimination models with the variables capturing the gender of the loan officer: Female loan officers or Female branch. The bank provided data on the exact gender-based composition of the bank branches for only 2006. The bank's executives assured us that this composition has remained stable over time and practically unchanged since 2004. Therefore, we first present our analysis for the entire sample of observations 
(both years: 2004 and 2006) and then verify the accuracy of our estimations by restricting the sample to the credit lines of only 2006.

In order to identify the motives that may drive female loan officers to behave differently from their male colleagues and the importance of gender-pairing, we interact the lender-gender variables with the length of the credit relationship and the gender of the loan applicant. Conditioning the effect of the decision-maker's gender on the length of the credit relationship allows us to assess the importance of women's risk attitude in shaping loan contracts. Over the course of the lending relationship, borrowers become established as ever more information is accumulated about them and uncertainty on their creditworthiness decreases. If the lower risk attitude and self-confidence of women are the motivation to adopt stricter loan criteria, we should observe that for 'established

borrowers the impact of the loan officer's gender is attenuated. However, the importance of negotiating with female loan officers is more pronounced for relatively new and `un-established borrowers.

Considering the gender pairing between lender and borrower allows us to ascertain whether the behavior of female loan officers is driven by a sort of "cultural affinity" or "solidarity" towards female borrowers or if, by contrast, it is influenced by "envy" for the success of other women and by subordination to the idea of the entrepreneur as a male category (Gupta et al. 2009).

\section{RESUltS}

\subsection{Loan applicants}

\section{A. Gender}

In tables 2 and 3 we report regression results for the gender discrimination models. In general, female business owners are significantly more likely to be asked for collateral (table 2, column 3). The probability that a female borrower has to pledge collateral is $6.1 \%$ higher than the probability 
for their male counterparts. Furthermore, women also face significantly stricter credit limits as they tend to overdraw $4.6 \%$ more often than men (table 2, column 5). However, after controlling for the nature of the bank-borrower relationship and characteristics of the lending branch we find that the interest rates paid by female entrepreneurs for the credit they use do not differ systematically from the rates paid by male business owners (table 2, column 1). Therefore, while there seems to be no gender-based discrimination in terms of price, female entrepreneurs tend to face tighter non-price contract terms. This result contrasts with that of Coleman (2000), but it is hardly surprising if we consider that the interest rate policy is typically decided at the bank level and its application on individual contracts is maneuverable only within narrow limits by loan officers.

\section{[INSERT TABLE 2 HERE]}

Since in the estimated models we do not have variables capturing the performance of the approved loans, at this stage we cannot say whether the differences in the contract terms reflect differential economic fundamentals between male and female borrowers rather than informationbased biases or loan officer preferences. In order to distinguish among these possible causes, we proceed in two steps. First, we augment the model with an interaction term between the borrower's gender and the length of bank-borrower relationship. As we stated above, if the tighter access to credit for female entrepreneurs reflects scarcity of information available to loan officers (statistical discrimination), the coefficient on Female_owner $\times$ Relationship_length should have the opposite sign of that on Female_owner. Regression results in columns 2, 4 and 6 clearly show that the more prudent behavior of loan officers when dealing with female entrepreneurs does not change over the course of the lending relationship. This suggests that the harsher credit restrictions are not the result of information-driven discrimination.

Hence the second step is to test for taste-driven gender discrimination. In this case, we exploit the longitudinal dimension of our dataset using panel data estimators to control for unobserved 
individual effects which could systematically differ across male and female entrepreneurs. However, as gender is time-invariant, in order to test for discrimination, we can only use GLS estimator assuming individual effects to be random. GLS regression results reported in table 3 show that in interest rate, collateral as well as credit availability models, the coefficients on the gender variable are very similar in sign, magnitude and statistical significance to those obtained in pooled regressions (see column 1 in table 2, and columns 3 and 6 in table 3 where for the sake of comparison we report results for linear probability models). However, the Hausman test rejects the hypothesis that all regressors are uncorrelated with the unobservable individual effects. We therefore re-estimate the interest rate, collateral and credit availability models by using the Hausman-Taylor estimator which allows for non-orthogonality between independent variables and individual effects. Assuming Rationing and Relationship length as endogenous variables, HT estimates (columns 2, 5 and 8) robustly confirm the negative impact of the entrepreneur's female gender on non-price loan conditions.

\section{[INSERT TABLE 3 HERE]}

Summing up, our findings suggest that on average female entrepreneurs do not pay for credit more than male entrepreneurs, but they face more stringent non-price conditions and tighter access to credit. Moreover, this negative effect seems at least partly due to lender preferences and beliefs about female entrepreneurs.

\section{B. Control variables}

Moving on to control variables, relational aspects of the lending relationship seem to be important determinants of the economic terms set in the loan contracts. First, the length of the relationship with the bank is associated with significantly lower interest rates, lower probability of firms pledging collateral and exceeding the credit limit established in the contract. Such benefits of longer 
bank-borrower relationships are consistent with the theoretical arguments advanced by Boot and Thakor (1994) and with the empirical evidence for the US provided, for example, by Petersen and Rajan (1994), Berger and Udell (1995) Chakraborty and Hu (2006) and Brick and Palia (2007). However, they are partly at odds with other studies for European countries and Japan, which show that while credit constraints are lower for firms with long-lasting bank ties, the interest rates and collateral requirements on small business lending tend to increase with the length of the lending relationship (Angelini et al. 1998; Degryse and Van Cayseele 2000; Hernandez and Martinez 2006; Ono and Uesugi 2005; Ogawa et al. 2007) ${ }^{7}$.

Second, the exclusivity of the bank-borrower relationship, Multiple lending, has mixed effects on the outcome of the lending process. Consistent with the idea advanced by Petersen and Rajan (1995) that banks need some degree of monopoly power over their borrowers in order for the benefits of the relational lending to materialize, we find that entrepreneurs who simultaneously borrow from multiple banks pay higher interest rates. However, these entrepreneurs also pledge real collateral as a guarantee for the credit they use less often and are less likely to overdraw costly funds. In any event, the statistical significance of Multiple lending is weak and limited to some specifications (see below, tables 6 and 7).

Third, consistent with the notion that the scope of the relationship allows banks to accumulate additional information which enhances their ability to assess and monitor their customers, we find that the use of other services by a borrower is associated with a lower probability that the loan applicants are asked to pledge collateral or that their borrowing exceeds the contractual limit. Interestingly, neither the scope of the lending relationship nor its exclusivity has a significant effect on the interest rate charged by the bank.

\footnotetext{
${ }^{7}$ An exception is Harhoff and Körting (1998) who, considering a sample of small and medium German enterprises, find, as we do, that as the lending relationship progresses the probability of pledging collateral decreases, while interest rates do not increase.
} 
The geographic proximity between the borrower and the lending branch, Branch-firm distance, and between the borrower and the branches of rival banks, Rivals-firm distance, also have significant effects on decisions concerning the interest rate, collateral and credit availability. In particular, borrowers operating closer to the lending branch are more likely to be asked for collateral, while they are less likely to overdraw on their credit lines. Moreover, contrary to the findings of Degryse and Ongena (2005), the greater the distance between the lending branch and the borrower, the higher the interest rate paid to the bank. Overall, such results seem to indicate that physical proximity to borrowers does not provide banks with additional market power, but it is a source of a competitive advantage which allows banks to offer contracts with lower interest rates and greater credit availability, but frequently covered by real collateral.

Consistently, the coefficients on Rivals-firm distance have the opposite sign of that on Branch-

firm distance in all specifications for all three dependent variables, even though the impact on interest rates is not significantly different from zero. Similarly, borrowers located in more concentrated markets, as measured by the Herfindahl-Hirschman Index $(H H I)$, tend to pay less for the credit they use and are less likely to be credit-constrained, suggesting the existence of information benefits associated with market concentration and market power.

Finally, as expected, overdrawing firms pay a higher interest rate, as shown by the positive and very significant coefficient on Rationing, while the size of borrowers is associated with lower interest rates. However, somewhat surprisingly Firm size is also correlated with a higher probability of collateral and has no significant effect on credit availability.

\subsection{Loan officers}

Now, we shift the focus from the borrower to the lender by augmenting our three models with variables designed to capture the role played by the gender of the loan officers who approve, 
monitor and service the credit lines. In Table 4 we present our results obtained with the entire sample of loan contracts, using the percentage of female loan officers at the lending branch as our main variable of interest.

\section{[INSERT TABLE 4 HERE]}

\section{A. Gender}

On average, the presence of female loan officers does not seem to significantly affect the interest rate paid by borrowers or the probability that they pledge collateral or overdraw funds. However, this average effect hides important heterogeneities. Our findings change when we try to distinguish among the motivations that could lead female officers to behave differently from males by conditioning the effect of loan officer gender on the gender pairing with borrowers or on the duration of the lending relationship.

First, we split the loan officer's gender variable according to the gender of the other party in the transaction by introducing two interaction terms. The coefficient on Female_LO $x$ Female_owner allows us to identify how female lenders react to female loan applicants compared to male officers, while Female_LO x Male_owner allows us to identify how female lenders react to male applicants. Our findings are mixed. On the one hand, female loan officers tend to charge lower interest rates when they offer credit to male entrepreneurs but the interest rates they charge to female entrepreneurs do not differ from the rates charged by male loan officers (table 4, column 2). On the other, female loan officers tend to ask female entrepreneurs for collateral less frequently, thus reducing the discrimination effect. In contrast, the probability that a male entrepreneur is asked to provide real guarantees in order to access credit does not differ among male and female lenders (column 5). Finally, the probability that the loan applicant has to rely on the costly option of overdrawing funds is not related to the specific gender-pairing (column 8). Overall, our findings suggest the existence of a sort of cultural affinity or gender solidarity that leads female lenders to 
make access to credit for female entrepreneurs easier, but not at lower interest rates. In this respect, on the contrary, female officers appear to feel a sense of subjection to male entrepreneurs, and when called to handle loan applications of male business owners they are inclined to approve them at lower interest rates.

Apart from cultural forces, a second motive that could drive female officers to decide differently on loan applications than male officers is their greater risk aversion or lower selfconfidence. In order to capture these motives, we condition the effect of the loan officer's gender on the length of the bank-borrower relationship by introducing an interaction term Female_LO $x$ Relationship_length in our regressions. If the degree of self-confidence and/or risk attitude influences the behavior of female lenders, we should observe that the differential effect of female officers is more significant for new borrowers, on which information is scarcer and credit risk greater. On the contrary, as the bank-borrower relationship progresses and information is accumulated, the impact of the loan officer's gender should be attenuated.

Regression results in table 4 confirm that the initial impact of the loan officer's gender decreases with relationship length: in all three models the coefficients on Female_LO $x$ Relationship_length have the opposite sign to those on the loan officer's gender. However, the mitigating effect of greater information is not statistically significant for the interest rate and collateral decisions (columns 3 and 6). By contrast, for new and "un-established" borrowers, the presence of more female loan officers at the lending branch significantly increases the probability that these borrowers will be credit-constrained and will have to use costly overdrawn funds to meet their financing needs. As the interaction between the bank and the entrepreneur extends over time, however, female loan officers seem not to behave differently from male officers.

In figures 1 and 2 we visualize the impact of the loan officer's gender on the incidence of collateral and the probability that a borrower overdraws. In order to avoid concerns with the appropriate 
treatment of interaction terms in nonlinear models (Ai and Norton 2003), we conduct the following exercises. First, keeping all other independent variables at their median values, we vary Relationship Length between 0 and its maximum value of 11,251 days. At each realization, we use the coefficients shown in columns 6 and 9 of table 4 to estimate the difference between the probabilities that the borrower will be asked to provide collateral and overdraw when Female Loan Officers equals 0 and when Female Loan Officers equals 1 . The series of these differences are shown in figures 1 and 2. Although lacking statistical significance, the impact of the loan officer's gender on the probability of pledging real collateral is substantial: a new borrower will be asked to provide collateral $10 \%$ more frequently if the loan officer is female (figure 1). The marginal impact of loan officer gender on the probability that the borrower will overdraw funds from the credit line is even greater: new and un-established borrowers are up to $15 \%$ more likely to exceed the limits of their credit lines when the loan officer is female (figure 2).

[INSERT FIGURES 1 AND 2 HERE]

Then we measure the persistence of the effect of loan officer's gender by calculating the value of Relationship length at which the differences in the marginal impacts of loan officer's gender are equal to zero in probability. Our calculations show that the impact of the loan officer's gender is confined within the first two years of the bank-borrower relationship when we consider the probability of pledging collateral and approximately three years and eight months when we focus on the probability that a borrower will face a binding credit limit.

\section{B. Control variables}

Relational distance as well as the other control variables which we used in the analysis of gender discrimination broadly retain their sign and significance when we include the loan officer's gender. However, since Female loan officers is branch-specific, and we cannot include fixed effects for 
branches in the regressions, in the lender's gender analysis we introduce some additional control variables for the operating environment and the organizational structure of the branches. Furthermore, standard errors are clustered at the bank branch level thus allowing for unobserved correlation among loans approved at the same branch.

Overall, these additional branch control variables have a weak impact on interest rates, collateral and credit availability. First of all, we find that branches that are part of industrial districts (District branch) can exploit the advantages of their contextual knowledge and thus fine-tune the credit contracts to the needs of their borrowers who, as a result, are less likely to overdraw their credit lines. However, the fact that the firm and the lending branch are located in an industrial district does not have any significant impact on the interest rate fixed in the loan contract and on the requested collateral.

Second, when the lending branch operates in a very populated credit market which is also probably large-sized, the credit limits set by the bank seem to be more narrow as shown by the positive coefficient on Bank population in the credit availability model. However, the economic effect seems to be very modest.

Finally, the distance between the local branch and the main headquarters of the bank, Branchheadquarters distance, is associated with a lower incidence of collateral and higher interest rates, while the contract terms of loans originated at the local headquarters, Main office, do not seem to differ systematically from those established in other branches.

\subsection{Robustness}

Our findings so far suggest that both the borrower's and lender's gender play an important role in shaping the lending relationship. In this section, by considering a different sample period and loan officer's gender variable, we provide two additional robustness checks for our findings. 
First, the bank provided the exact gender composition of each bank branch only for 2006. On the basis of informal talks with the CEO and other managers of the bank, we assumed in the analysis in the previous section that this composition remained stable after 2004. We now verify whether our results are maintained when we restrict the analysis to loans approved during 2006. The estimation results (table 5) show that the sign and significance of gender and control variables remain overall unchanged. A minor exception is that when we consider the gender pairing, female loan officers who deal with female entrepreneurs are no longer significantly associated with lower collateral incidence (the p-value of Female_LO x Male_owner is 0.813; see column 5).

\section{[INSERT TABLE 5 HERE]}

Second, the proxy we used for the loan officer's gender, the percentage of female officers at the lending branch, is branch-specific rather than contract-specific. In other words, we have no information on who is the loan officer handling each loan contract. Under the assumption that the assignment of borrowers to loan officers is random with respect to the gender of the two parties, our measure captures the average probability that a particular credit line is serviced by a female loan officer. However, we cannot exclude the existence of a gender bias in the allocation of loan applicants to loan officers. In order to take into consideration such a possible bias, we re-estimate our models using the sub-sample of credit lines originated at bank branches which are populated by either only male or only female loan officers and include a dummy variable, Only female loan officers, taking the value of 1 for loans approved at female-populated branches. The results of this analysis are reported in table 6 for the 2004-06 period, and in table 7 for 2006 only.

\section{[INSERT TABLE 6 HERE]}

The cultural affinity and risk-aversion effects that we documented with respect to the likelihood of borrowers pledging collateral and overdrawing are confirmed. Specifically, the probability that a female entrepreneur will be asked to provide collateral is 4.8 percent lower at branches which 
employ only female loan officers. In addition, as in table 4, new borrowers are more likely to face binding limits on their credit lines if all lenders at the branch are females and the effect is decreasing with the length of the lending relationship. Importantly, the gender-pairing effect documented for interest rates is no longer significant.

When we restrict our attention to 2006 data, the gender-pairing effects disappear (the p-values on Only female LO x Male owner and Only female LO x Female owner are respectively 0.12 and 0.69 in the interest rate regression and 0.3 and 0.13 in the collateral regression) but the risk-aversion effect is preserved, as shown by the significance of the interaction term between the dummy for female branches and the length of the bank-borrower relationship.

[INSERT TABLE 7 HERE]

\section{Conclusion}

In this paper we analyzed the relevance of the gender of the parties involved in a lending transaction for shaping the price and non-price terms of the contract. First, we show that female entrepreneurs face tighter access to credit, even though the interest rates they pay do not differ from those paid by male business owners. This discrimination effect is independent of the information available about the borrower and holds in panel regressions where unobservable individual firm effects are taken into account. In view of these findings, our evidence is consistent (or, at least, not inconsistent) with the taste-based discrimination theory. However to further understand the underlying economic forces, additional analysis for differences in riskiness between male- and female-owned small businesses would be desirable.

Second, when we look at the impact of the loan officer's gender on the outcome of the lending process we find that female officers are more risk-averse or less self-confident than male officers as they tend to restrict credit availability to new, unestablished borrowers more than their male 
counterparts. Moreover, female officers appear to show more solidarity with female borrowers, who are required to pledge collateral less often, and greater subjection to male entrepreneurs, who are granted credit at lower interest rates. 


\section{REFERENCES}

Agarwal S. and F.H. Wang (2008). "Motivating loan officers: an analysis of salaries and piece rates compensation." Federal Reserve Bank of Chicago Working paper, available at http://papers.ssrn.com/sol3/papers.cfm?abstract_id=1287689

Agarwal S. and R. Hauswald (2008). "Distance and Private Information in Lending." American University Working paper, Washington.

Ai C. and E.C. Norton (2003). "Interaction terms in logit and probit models." Economics Letters 80, 123-129.

Alessandrini P., A.F. Presbitero and A. Zazzaro (2009). "Banks, distances and firms' financing constraints." Review of Finance, 13, 261-307

Alessandrini P. and A. Zazzaro (2009), "Banks' localism and industrial districts." In G. Becattini, M. Bellandi and L. De Propris (eds), A Handbook of Industrial districts, Cheltenam: Edward Elgar.

Alesina, A., F. Lotti and P.E. Mistrulli (2008). "Do women pay more for credit? Evidence from Italy." NBER Working paper, No. 14202.

Andersson P. (2004). "Does experience matter in lending? A process-tracing study on experienced loan officers' and novices' decision behavior." Journal of Economic Psychology 25, 471-92.

Angelini P., R. Di Salvo R. and G. Ferri (1998). "Availability and cost of credit for small business: customer relationships and credit cooperatives." Journal of Banking and Finance, 22, 925-954.

Barber B.M. and T. Odean (2001). "Boys will be boys: gender, overconfidence, and common stock investment." Quarterly Journal of Economics 116, 261-92.

Berger A.N. and G.F. Udell (1995). "Relationship lending and lines of credit in small firm finance." The Journal of Business 68, 351-381.

Berger A.N., N.H. Miller, M.A. Petersen, R.G. Rajan and J.C. Stein (2005). "Does function follow organizational form? Evidence from the lending practices of large and small banks." Journal of Financial Economics 76, 237-269.

Beck T., P. Behr and A. Güttler (2009). "Are women better loan officers?" Tilburg University, available at http://siteresources.worldbank.org/INTFR/Resources/Becketal022409.pdf

Ben-Ne, A., F. Kon, and L. Putterman (2004). "Share and share alike? Gender-pairing, personality, and cognitive ability as determinants of giving." Journal of Economic Psychology 25, 581-589.

Blanchflower D.G., P.B. Levine and D.J. Zimmerman (2003). "Discrimination in the small-business credit market." The Review of Economics and Statistics 85, 930-943. 
Boot, A. (2000). " Relationship banking: what do we know?" Journal of Financial Intermediation 9, $7-25$.

Boot A. and A. Thakor (1994). "Moral hazard and secured lending in an infinitely repeated credit market game." International Economic Review 35, 899-920.

Brevoort K.P. and J.P. Wolken (2009). "Does distance matter in banking." In P. Alessandrini, M. Fratianni and A. Zazzaro. (Eds.) "The Changing Geography of Banking and Finance." New York: Springer.

Byrnes J.P., D.C. Miller and W D. Schafer (1999). "Gender differences in risk taking: a meta analysis." Psychological Bulletin 125, 367-383.

Calcagnini G. and E. Lenti (2008). "L'accesso al credito per l'imprenditoria femminile." In A. Zazzaro (ed.) I vincoli finanziari alla crescita delle imprese, Roma: Carocci .

Calem P. and M. Stutzer (1995). "The simple analytics of observed discrimination in credit markets." Journal of Financial Intermediation 4, 189-212.

Carletti E., V. Cerasi and S. Daltung (2007). "Multiple-bank lending: diversification and free-riding in monitoring." Journal of Financial Intermediation 16, 425-451.

Carling K. and S. Lundberg (2005). "Asymmetric information and distance. An empirical assessment of geographical credit rationing." Journal of Economics and Business 57, 39-59.

Carter S., E. Shaw, W. Lam and F. Wilson (2007). "Gender, entrepreneurship, and bank lending: the criteria and processes used by bank loan officers in assessing applications." Entrepreneurship: Theory and Practice 31, 427-444.

Cavalluzzo K.S. and L.C. Cavalluzzo (1998). "Market structure and discrimination: the case of small businesses." Journal of Money, Credit and Banking 30, 771-792.

Cavalluzzo K.S., L.C. Cavalluzzo and J.D. Wolken (2002). "Competition, small business financing, and discrimination: evidence from a new survey." The Journal of Business 75, 641-679.

Cerqueiro G., H. Degryse and S. Ongena (2007). "Rules versus discretion in loan rate setting." CentER Discussion paper No. 59, Tilburg University.

Chakraborty A. and C.X. Hu (2006). "Lending relationships in line-of-credit and nonline-of-credit loans: evidence from collateral use in small business." Journal of Financial Intermediation 15, 86-107.

Cole R.A. (1998). "The importance of relationships to the availability of credit." Journal of Banking and Finance 22, 959-977. 
Cole R.A. and H. Mehran (2009). "Gender and the availability of credit to privately held firms: evidence from the Surveys of Small Business Finances." FRBNY Staff Report No. 383.

Coleman S. (2000). "Access to capital and terms of credit: a comparison of men- and womenowned small businesses." Journal of Small Business Management 38, 37-52.

Croson R. and U. Gneezy (2009). "Gender differences in preferences." Journal of Economic Literature 47, 448474.

D'Auria C., A. Foglia and P. M. Reedtz (1999). "Bank interest rates and credit relationships in Italy." Journal of Banking and Finance 23 , 1067-1093.

Degryse H., and P. Van Cayseele (2000). "Relationship lending within a bank-based system: evidence from European small business data." Journal of Financial Intermediation 9, 90-109.

Degryse H. and S. Ongena (2005). "Distance, lending relationships, and competition." The Journal of Finance 60, 231-266.

Detragiache E., P. Garella and L. Guiso (2002). "Multiple versus single banking relationships: theory and evidence." The Journal of Finance 55, 1133-1161.

DeYoung R., D. Glennon and P. Nigro (2008). "Borrower-lender distance, credit scoring, and loan performance: evidence from informationally opaque small business borrowers." Journal of Financial Intermediation 17, 113-143.

Dufwenberg M. and A. Muren (2006). "Generosity, anonymity, gender." Journal of Economic Behavior \& Organization 61, 42-49.

Eckel C. and P. Grossman (2001). "Chivalry and solidarity in ultimatum games." Economic Inquiry 39, 171-88.

Eckel C.C. and P.J. Grossman (2008). "Forecasting risk attitudes: an experimental study using actual and forecast gamble choices." Journal of Economic Behavior \& Organization, 68, 1-17.

Favaretto I. (2007). "L'imprenditoria femminile nelle "aree spaziali" della provincia di PesaroUrbino." In I. Favaretto (ed.) Quanto vale la differenza. L'imprenditoria femminile come fattore di sviluppo locale, Milano: Franco Angeli.

Gambini, A. and A. Zazzaro. "Who captures who? Long-lasting bank relationships and growth of firms." MoFiR Working paper No. 22, Università Politecnica delle Marche, Ancona.

Gilligan C. (1982). In a Different Voice: Women's Conceptions of the Self and of Morality. Cambridge, MA: Harvard University Press.

Gneezy U., M. Niederle and A. Rustichini (2003). "Performance in competitive environments: Gender differences." Quarterly Journal of Economics 118, 1049-74. 
Guelpa F. and V. Tirri (2006). "The effect of market structure and relationship lending on the likelihood of credit tightening." Paper presented at the conference "The Changing Geography of Banking", Ancona, available at http://geographybanking.univpm.it.

Gupta N., A. Poulsen and M.-C. Villeval (2005). "Male and female competitive behavior: experimental evidence." IZA Discussion Paper No. 1833.

Gupta V., D. Turban, S. Wasti and A. Sikdar (2009). "The role of gender stereotypes in perceptions of entrepreneurs and intentions to become an entrepreneur." Entrepreneurship Theory and Practice 33, 397-417.

Harhoff D. and T. Körting (1998). "Lending relationships in Germany. Empirical evidence from survey data." Journal of Banking and Finance 22 (1998), 1317-1353.

Hausman J. A. and W.E. Taylor (1981). "Panel data and unobservable individual effects." Econometrica 49, 1377-1398.

Hernandez G. and P. Martinez (2006). "Banking relationships: effects on the debt terms for small Spanish firms. " Journal of Small Business Management, 44, 315-333.

Hertzberg A., J.M. Liberti and D. Paravisini (2009). "Information and incentives inside the firm: evidence from loan officer rotation." Journal of Finance, forthcoming.

Muravyev A., D. Schäfer and O. Talavera (2009). "Entrepreneurs' gender and financial constraints: evidence from international data." Journal of Comparative Economics 37, 270-286.

Ono A. and I. Uesugi (2005). "The role of collateral and personal guarantees in relationship lending: evidence from Japan's small business loan market." RIETI Discussion paper No. 27. ,

Ogawa K., E. Sterken and I. Tokutsu (2007). "Why do Japanese firms prefer multiple bank relationship? Some evidence from firm-level data." Economic Systems 31, 49-70.

Palia D. and I. Brick (2007). "Evidence of jointness in the terms of relationship lending." Journal of Financial Intermediation 16, 452-476.

Petersen M.A. and R.G. Rajan (1994). "The benefits of lending relationships: evidence from small business data." The Journal of Finance 49, 3-37.

(1995). "The effect of credit market competition on lending relationships." The Quarterly Journal of Economics 110, 407-443.

- (2002). "Does distance still matter? The information revolution in small business lending." Journal of Finance 57, 2533-2570.

Powell M. and D. Ansic (1997), "Gender differences in risk behaviour in financial decision-making: an experimental analysis", Journal of Economic Psychology, 18(6), 605-628. 
Ravina E. (2008). "Love \& Loans: The Effect of Beauty and Personal Characteristics in Credit Markets." Working paper, New York University, available at http://ssrn.com/abstract=1101647.

Robb A. and J.D. Wolken (2002). "Firm, owner, and financing characteristics: differences between female- and male-owned small businesses." FEDS Working paper No. 18.

Scalera D. and A. Zazzaro (2001). "Group reputation and persistent (or permanent) discrimination in credit markets." Journal of Multinational Financial Management 11, 483-96.

Uchida H., G.F. Udell and N. Yamori (2006). "Loan officers and relationship lending." RIETI Discussion paper.

Walker H. and M. Fennell (1986). "Gender differences in role differentiation and organizational performance." Annual Review of Sociology 12, 255-275.

Wilson F., S. Carter, S. Tagg, E. Shaw and W. Lamz (2007). "Bank loan officers' perceptions of business owners: the role of gender." British Journal of Management 18 , 154-171. 
TABLE 1 SUMmary STATISTICS

\begin{tabular}{|c|c|c|c|c|c|c|c|}
\hline & \multicolumn{2}{|c|}{ All firms } & \multicolumn{2}{|c|}{ Male owner } & \multicolumn{2}{|c|}{ Female owner } & \multirow{2}{*}{$\begin{array}{c}\begin{array}{c}\text { Means } \\
\text { differences }\end{array} \\
\text { p-values }\end{array}$} \\
\hline & Mean & St. dev. & Mean & St. dev. & Mean & St. dev. & \\
\hline \multicolumn{8}{|l|}{ Dependent variables } \\
\hline Interest rate & 7.097 & $(2.631)$ & 7.076 & $(2.607)$ & 7.173 & $(2.712)$ & 0.205 \\
\hline Collateral & 0.350 & $(0.477)$ & 0.341 & $(0.474)$ & 0.381 & $(0.486)$ & 0.004 \\
\hline Credit availability & 0.375 & $(0.484)$ & 0.351 & $(0.477)$ & 0.459 & $(0.498)$ & 0.000 \\
\hline \multicolumn{8}{|l|}{ Gender variables } \\
\hline Female owner & 0.227 & $(0.419)$ & & & & & \\
\hline Female loan officers (\%) & 0.287 & $(0.321)$ & 0.284 & $(0.324)$ & 0.298 & $(0.312)$ & 0.104 \\
\hline Only female loan officers & 0.075 & $(0.263)$ & 0.078 & $(0.268)$ & 0.065 & $(0.247)$ & 0.084 \\
\hline \multicolumn{8}{|l|}{ Control variables } \\
\hline Firm Size & 1.226 & $(0.505)$ & 1.238 & $(0.514)$ & 1.183 & $(0.470)$ & 0.000 \\
\hline Relationship length (in days) & 3057 & $(2742)$ & 3226 & $(2829)$ & 2459 & $(2310)$ & 0.000 \\
\hline Multiple lending & 0.968 & $(0.177)$ & 0.969 & $(0.172)$ & 0.962 & $(0.192)$ & 0.104 \\
\hline Other services & 0.901 & $(0.298)$ & 0.912 & $(0.283)$ & 0.865 & $(0.341)$ & 0.000 \\
\hline Branch-firm distance $(\mathrm{km})$ & 4.659 & $(6.551)$ & 4.806 & $(6.560)$ & 4.137 & $(6.496)$ & 0.001 \\
\hline Branch-headquarter distance $(\mathrm{km})$ & 40.42 & $(32.84)$ & 40.15 & $(32.73)$ & 41.32 & $(33.22)$ & 0.188 \\
\hline Rivals- firm distance $(\mathrm{km})$ & 3.414 & $(4.753)$ & 3.576 & $(4.925)$ & 2.842 & $(4.039)$ & 0.000 \\
\hline Main office & 0.196 & $(0.397)$ & 0.188 & $(0.391)$ & 0.225 & $(0.418)$ & 0.000 \\
\hline District branch & 0.570 & $(0.495)$ & 0.567 & $(0.495)$ & 0.579 & $(0.494)$ & 0.370 \\
\hline HHI & 0.263 & $(0.227)$ & 0.267 & $(0.231)$ & 0.249 & $(0.213)$ & 0.003 \\
\hline
\end{tabular}

Note: The table presents summary statistics for the sample used in the multivariate analysis. Construction and definition of each variable can be found in the Appendix. The first two columns show the mean value for each variable followed by its standard deviation in parentheses. Columns (3) and (4) show the mean and standard deviation (in parentheses) of each variable for the subsample of firms owned by male entrepreneurs. Columns (5) and (6) show the same statistics for the subsample of firms owned by female entrepreneurs. The last column shows the p-values of a t-test of equality of the means of each variable across the two subsamples. 


\begin{tabular}{|c|c|c|c|c|c|c|}
\hline \multirow{4}{*}{ Female owner } & \multicolumn{6}{|c|}{ Dependent Variables } \\
\hline & \multicolumn{2}{|c|}{ Interest rate } & \multicolumn{2}{|c|}{ Collateral } & \multicolumn{2}{|c|}{ Credit Availability } \\
\hline & -0.075 & -0.335 & $0.166 * * *$ & 0.041 & $0.123 * * *$ & 0.112 \\
\hline & $(0.080)$ & $(0.523)$ & $(0.045)$ & $(0.256)$ & $(0.044)$ & $(0.315)$ \\
\hline \multirow[t]{2}{*}{ Relationship length } & $-0.142 * * *$ & $-0.150 * * *$ & $-0.049 * * *$ & $-0.053 * * *$ & $-0.338 * * *$ & $-0.338 * * *$ \\
\hline & $(0.032)$ & $(0.036)$ & $(0.016)$ & $(0.018)$ & $(0.018)$ & $(0.020)$ \\
\hline \multirow[t]{2}{*}{ Female owner x Relationship length } & & 0.035 & & 0.017 & & 0.001 \\
\hline & & $(0.068)$ & & $(0.034)$ & & $(0.042)$ \\
\hline \multirow{2}{*}{ Multiple lending } & 0.154 & 0.155 & $-0.310 * * *$ & $-0.311 * * *$ & -0.064 & -0.064 \\
\hline & $(0.183)$ & $(0.183)$ & $(0.093)$ & $(0.094)$ & $(0.109)$ & $(0.109)$ \\
\hline \multirow[t]{2}{*}{ Other services } & 0.134 & 0.133 & $-0.326 * * *$ & $-0.327 * * *$ & $-0.917 * * *$ & $-0.917 * * *$ \\
\hline & $(0.113)$ & $(0.113)$ & $(0.056)$ & $(0.056)$ & $(0.058)$ & $(0.058)$ \\
\hline \multirow[t]{2}{*}{ Firm size } & $-0.119 * *$ & $-0.118 * *$ & $0.127 * * *$ & $0.127 * * *$ & -0.049 & -0.049 \\
\hline & $(0.060)$ & $(0.060)$ & $(0.036)$ & $(0.036)$ & $(0.035)$ & $(0.035)$ \\
\hline \multirow[t]{2}{*}{ Rationing } & $0.645 * * *$ & $0.645 * * *$ & & & & \\
\hline & $(0.071)$ & $(0.071)$ & & & & \\
\hline \multirow[t]{2}{*}{ HHI } & -0.260 & -0.261 & $0.218 * *$ & $0.217 * *$ & $-0.299 * * *$ & $-0.299 * * *$ \\
\hline & $(0.167)$ & $(0.167)$ & $(0.101)$ & $(0.101)$ & $(0.101)$ & $(0.101)$ \\
\hline \multirow[t]{2}{*}{ Branch - firm distance } & $0.088 * *$ & $0.088 * *$ & $-0.048 * *$ & $-0.048 * *$ & $0.074 * * *$ & $0.074 * * *$ \\
\hline & $(0.043)$ & $(0.043)$ & $(0.024)$ & $(0.024)$ & $(0.023)$ & $(0.023)$ \\
\hline \multirow[t]{2}{*}{ Rivals - firm distance } & -0.055 & -0.056 & $0.063 * *$ & $0.062 * *$ & $-0.106 * * *$ & $-0.106 * * *$ \\
\hline & $(0.052)$ & $(0.052)$ & $(0.029)$ & $(0.029)$ & $(0.028)$ & $(0.028)$ \\
\hline \multirow[t]{2}{*}{ Year 2004} & $-1.083 * * *$ & $-1.083 * * *$ & $-1.225^{* * *}$ & $-1.224 * * *$ & $-0.120 * * *$ & $-0.120 * * *$ \\
\hline & $(0.063)$ & $(0.063)$ & $(0.038)$ & $(0.038)$ & $(0.036)$ & $(0.036)$ \\
\hline \multirow[t]{2}{*}{ Intercept } & $8.106 * * *$ & $8.162 * * *$ & $0.604 * *$ & $0.633 * *$ & $3.302 * * *$ & $3.304 * * *$ \\
\hline & $(0.495)$ & $(0.512)$ & $(0.277)$ & $(0.284)$ & $(0.312)$ & $(0.317)$ \\
\hline Industry/Time effects & Yes & Yes & Yes & Yes & Yes & Yes \\
\hline Branch effects & Yes & Yes & Yes & Yes & Yes & Yes \\
\hline Observations & 6414 & 6414 & 6465 & 6465 & 6412 & 6412 \\
\hline $\mathrm{R} 2$ & 0.12 & 0.12 & 0.18 & 0.18 & 0.15 & 0.15 \\
\hline
\end{tabular}

Note: The table presents multivariate analysis of the impact of borrower's gender on loan contract terms. Columns (1) and (2) show the results from OLS regressions with dependent variable the Interest rate charged by the bank. Columns (3) and (4) show the results from Probit models with dependent variable Collateral that takes the value of 1 if the credit line is collateralized and 0 otherwise. Columns (5) and (6) show the results from Probit models with dependent variable Credit availability which takes the value of 1 if the firm exceeds the amount granted on the credit line by the bank and 0 if the firm borrows less than the credit limit or exhausts the full credit. The table reports point estimates of the coefficients, followed by their robust standard errors in parentheses. Each regression includes industry and bank branch effects and is corrected for clustering of standard errors at the bank branch level. The definition and construction of the variables is in the Appendix. 


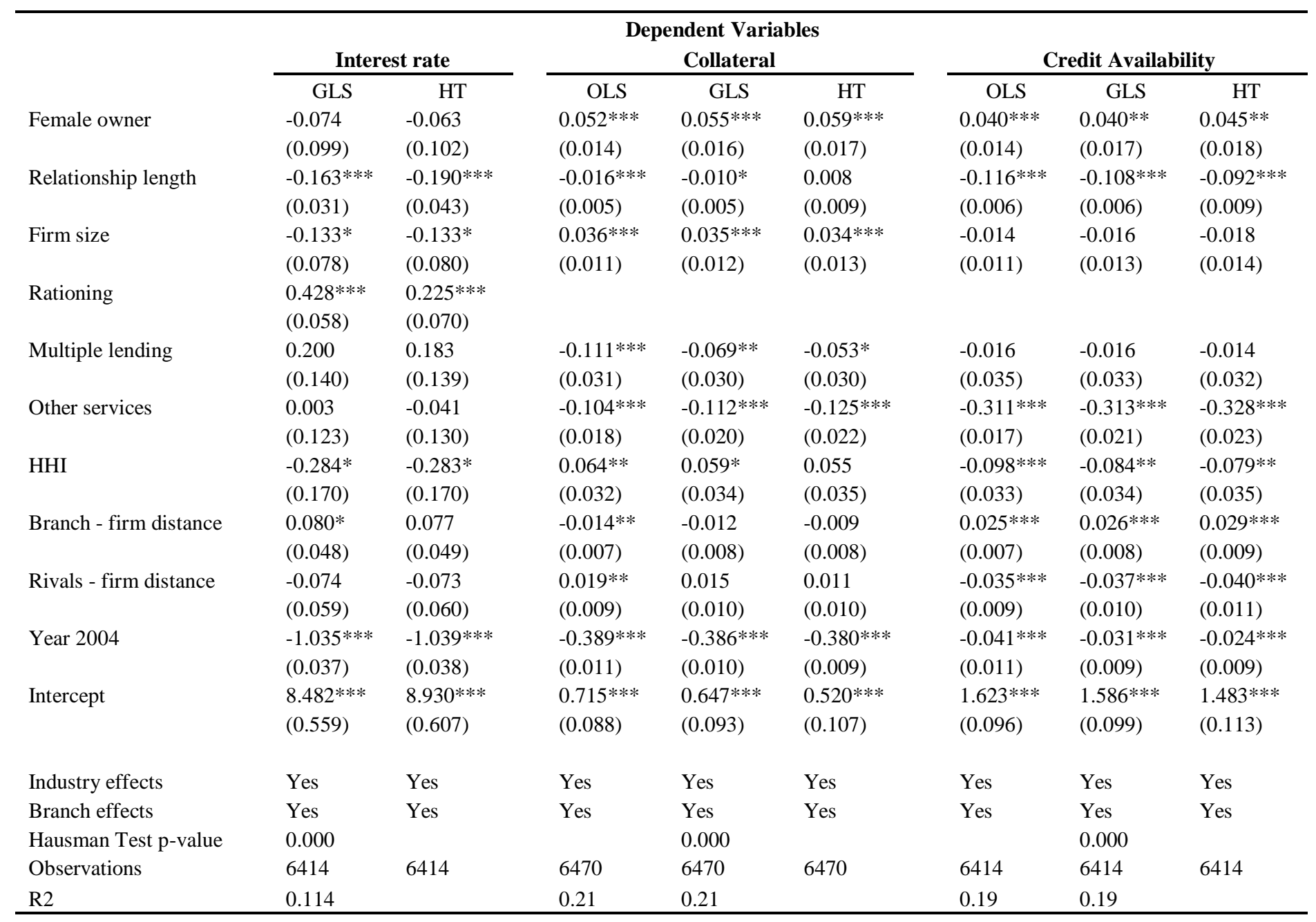

Note: The table presents multivariate analysis of the impact of the loan applicant's gender on loan contract terms. The dependent variable in columns (1) and (2) is the Interest rate charged by the bank. Column (1) shows results from GLS regressions model with borrower-specific random effects. Column (2) shows the results from Hausman-Taylor estimation with Relationship length and Rationing as endogenous variables. The dependent variable in columns (3), (4) and (5) is Collateral and takes the value of 1 if the credit line is collateralized and 0 otherwise. Column (3) shows the results of an estimation of a linear probability model. Column (4) shows the results of a GLS estimation of a random-effects model. Column (5) shows the results of a Hausman-Taylor estimation with Relationship Length as endogenous variable. The dependent variable in columns (6), (7) and (8) is Credit availability and takes the value of 1 if the borrower overdraws costly funds from the credit line and 0 if the borrower exhausts the credit 
amount or borrows strictly less than the amount granted by the bank. Column (6) shows the results of an estimation of a linear probability model. Column (7) shows the results of a GLS estimation of a model with borrower-specific random effects. Column (8) shows that results of HausmanTaylor estimation with Relationship length as endogenous variable. The table reports point estimates of the coefficients, followed by their standard errors in parentheses. Each regression includes industry and bank-branch fixed effects The definitions and construction of the variables are in the Appendix. 
TABle 4: LoAN OfFicer Gender ANALYSIS - Full SAMPLE

\begin{tabular}{|c|c|c|c|c|c|c|c|c|c|}
\hline \multirow[b]{3}{*}{ Female owner } & \multicolumn{9}{|c|}{ Dependent Variables } \\
\hline & \multicolumn{3}{|c|}{ Interest rate } & \multicolumn{3}{|c|}{ Collateral } & \multicolumn{3}{|c|}{ Credit Availability } \\
\hline & $\begin{array}{l}-0.040 \\
(0.108)\end{array}$ & $\begin{array}{l}-0.121 \\
(0.143)\end{array}$ & $\begin{array}{l}-0.040 \\
(0.108)\end{array}$ & $\begin{array}{l}0.166 * * * \\
(0.055)\end{array}$ & $\begin{array}{l}0.247 * * * \\
(0.076)\end{array}$ & $\begin{array}{l}0.165 * * * \\
(0.055)\end{array}$ & $\begin{array}{l}0.138 * * * \\
(0.042)\end{array}$ & $\begin{array}{l}0.113 * \\
(0.064)\end{array}$ & $\begin{array}{l}0.137 * * * \\
(0.042)\end{array}$ \\
\hline Relationship length & $\begin{array}{l}-0.091 * \\
(0.051)\end{array}$ & $\begin{array}{l}-0.091 * \\
(0.051)\end{array}$ & $\begin{array}{l}-0.075 \\
(0.081)\end{array}$ & $\begin{array}{l}-0.034 * \\
(0.019)\end{array}$ & $\begin{array}{l}-0.035^{*} \\
(0.019)\end{array}$ & $\begin{array}{l}-0.023 \\
(0.022)\end{array}$ & $\begin{array}{l}-0.308 * * * \\
(0.023)\end{array}$ & $\begin{array}{l}-0.307 * * * \\
(0.023)\end{array}$ & $\begin{array}{l}-0.266 * * * \\
(0.027)\end{array}$ \\
\hline Female loan officers (in \%) & $\begin{array}{l}-0.250 \\
(0.170)\end{array}$ & & $\begin{array}{l}0.138 \\
(1.132)\end{array}$ & $\begin{array}{l}-0.011 \\
(0.061)\end{array}$ & & $\begin{array}{l}0.256 \\
(0.481)\end{array}$ & $\begin{array}{l}-0.115 \\
(0.096)\end{array}$ & & $\begin{array}{l}0.903 * * \\
(0.456)\end{array}$ \\
\hline Female LO x male owner & & $\begin{array}{l}-0.307^{*} \\
(0.170)\end{array}$ & & & $\begin{array}{l}0.046 \\
(0.077)\end{array}$ & & & $\begin{array}{l}-0.134 \\
(0.104)\end{array}$ & \\
\hline Female LO $\mathrm{x}$ female owner & & $\begin{array}{l}-0.041 \\
(0.286)\end{array}$ & & & $\begin{array}{l}-0.223^{*} \\
(0.122)\end{array}$ & & & $\begin{array}{l}-0.050 \\
(0.126)\end{array}$ & \\
\hline Female LO $\mathrm{x}$ relationship length & & & $\begin{array}{l}-0.052 \\
(0.144)\end{array}$ & & & $\begin{array}{l}-0.036 \\
(0.066)\end{array}$ & & & $\begin{array}{l}-0.137 * * \\
(0.062)\end{array}$ \\
\hline Firm size & $\begin{array}{l}-0.137 \\
(0.089)\end{array}$ & $\begin{array}{l}-0.138 \\
(0.088)\end{array}$ & $\begin{array}{l}-0.137 \\
(0.089)\end{array}$ & $\begin{array}{l}0.132 * * * \\
(0.044)\end{array}$ & $\begin{array}{l}0.133 * * * \\
(0.044)\end{array}$ & $\begin{array}{l}0.132 * * * \\
(0.044)\end{array}$ & $\begin{array}{l}-0.059 \\
(0.038)\end{array}$ & $\begin{array}{l}-0.060 \\
(0.038)\end{array}$ & $\begin{array}{l}-0.060 \\
(0.038)\end{array}$ \\
\hline Rationing & $\begin{array}{l}0.696 * * * \\
(0.086)\end{array}$ & $\begin{array}{l}0.695 * * * \\
(0.086)\end{array}$ & $\begin{array}{l}0.695 * * * \\
(0.086)\end{array}$ & & & & & & \\
\hline Multiple lending & $\begin{array}{l}0.106 \\
(0.162)\end{array}$ & $\begin{array}{l}0.100 \\
(0.162)\end{array}$ & $\begin{array}{l}0.108 \\
(0.162)\end{array}$ & $\begin{array}{l}-0.327 * * * \\
(0.095)\end{array}$ & $\begin{array}{l}-0.322 * * * \\
(0.095)\end{array}$ & $\begin{array}{l}-0.326 * * * \\
(0.095)\end{array}$ & $\begin{array}{l}-0.055 \\
(0.123)\end{array}$ & $\begin{array}{l}-0.057 \\
(0.123)\end{array}$ & $\begin{array}{l}-0.052 \\
(0.124)\end{array}$ \\
\hline Other services & $\begin{array}{l}0.094 \\
(0.151)\end{array}$ & $\begin{array}{l}0.096 \\
(0.151)\end{array}$ & $\begin{array}{l}0.094 \\
(0.151)\end{array}$ & $\begin{array}{l}-0.331 * * * \\
(0.060)\end{array}$ & $\begin{array}{l}-0.334 * * * \\
(0.059)\end{array}$ & $\begin{array}{l}-0.331 * * * \\
(0.060)\end{array}$ & $\begin{array}{l}-0.918 * * * \\
(0.064)\end{array}$ & $\begin{array}{l}-0.918 * * * \\
(0.064)\end{array}$ & $\begin{array}{l}-0.918 * * * \\
(0.065)\end{array}$ \\
\hline HHI & $\begin{array}{l}-0.398 * * \\
(0.172)\end{array}$ & $\begin{array}{l}-0.406 * * \\
(0.172)\end{array}$ & $\begin{array}{l}-0.404 * * \\
(0.173)\end{array}$ & $\begin{array}{l}0.147 \\
(0.099)\end{array}$ & $\begin{array}{l}0.155 \\
(0.101)\end{array}$ & $\begin{array}{l}0.143 \\
(0.099)\end{array}$ & $\begin{array}{l}-0.112 \\
(0.104)\end{array}$ & $\begin{array}{l}-0.114 \\
(0.104)\end{array}$ & $\begin{array}{l}-0.127 \\
(0.102)\end{array}$ \\
\hline Main office & $\begin{array}{l}0.281 \\
(0.195)\end{array}$ & $\begin{array}{l}0.276 \\
(0.196)\end{array}$ & $\begin{array}{l}0.280 \\
(0.195)\end{array}$ & $\begin{array}{l}0.169 * \\
(0.091)\end{array}$ & $\begin{array}{l}0.175^{*} \\
(0.091)\end{array}$ & $\begin{array}{l}0.169 * \\
(0.091)\end{array}$ & $\begin{array}{l}-0.080 \\
(0.076)\end{array}$ & $\begin{array}{l}-0.082 \\
(0.076)\end{array}$ & $\begin{array}{l}-0.084 \\
(0.078)\end{array}$ \\
\hline District branch & $\begin{array}{l}-0.026 \\
(0.127)\end{array}$ & $\begin{array}{l}-0.027 \\
(0.127)\end{array}$ & $\begin{array}{l}-0.028 \\
(0.126)\end{array}$ & $\begin{array}{l}-0.007 \\
(0.057)\end{array}$ & $\begin{array}{l}-0.005 \\
(0.057)\end{array}$ & $\begin{array}{l}-0.008 \\
(0.057)\end{array}$ & $\begin{array}{l}-0.133^{* * *} \\
(0.051)\end{array}$ & $\begin{array}{l}-0.134^{* * * *} \\
(0.051)\end{array}$ & $\begin{array}{l}-0.138 * * * \\
(0.051)\end{array}$ \\
\hline Branch population & $\begin{array}{l}0.001 \\
(0.002)\end{array}$ & $\begin{array}{l}0.001 \\
(0.002)\end{array}$ & $\begin{array}{l}0.001 \\
(0.003)\end{array}$ & $\begin{array}{l}-0.000 \\
(0.001)\end{array}$ & $\begin{array}{l}-0.000 \\
(0.001)\end{array}$ & $\begin{array}{l}-0.000 \\
(0.001)\end{array}$ & $\begin{array}{l}0.001 * \\
(0.001)\end{array}$ & $\begin{array}{l}0.001 * \\
(0.001)\end{array}$ & $\begin{array}{l}0.001 * \\
(0.001)\end{array}$ \\
\hline Branch - headquarter distance & $\begin{array}{l}0.109 * \\
(0.063)\end{array}$ & $\begin{array}{l}0.109 * \\
(0.062)\end{array}$ & $\begin{array}{l}0.107 * \\
(0.062)\end{array}$ & $\begin{array}{l}-0.076^{* * *} \\
(0.020)\end{array}$ & $\begin{array}{l}-0.076 * * * \\
(0.020)\end{array}$ & $\begin{array}{l}-0.077 * * * \\
(0.021)\end{array}$ & $\begin{array}{l}0.007 \\
(0.026)\end{array}$ & $\begin{array}{l}0.008 \\
(0.026)\end{array}$ & $\begin{array}{l}0.003 \\
(0.025)\end{array}$ \\
\hline Branch - firm distance & $\begin{array}{l}0.097 * \\
(0.056)\end{array}$ & $\begin{array}{l}0.099 * \\
(0.056)\end{array}$ & $\begin{array}{l}0.099 * \\
(0.056)\end{array}$ & $\begin{array}{l}-0.054 * * \\
(0.023)\end{array}$ & $\begin{array}{l}-0.056 * * \\
(0.024)\end{array}$ & $\begin{array}{l}-0.053 * * \\
(0.023)\end{array}$ & $\begin{array}{l}0.064 * * \\
(0.027)\end{array}$ & $\begin{array}{l}0.064 * * \\
(0.027)\end{array}$ & $\begin{array}{l}0.068 * * * \\
(0.026)\end{array}$ \\
\hline Rivals - firm distance & $\begin{array}{l}-0.041 \\
(0.069)\end{array}$ & $\begin{array}{l}-0.042 \\
(0.069)\end{array}$ & $\begin{array}{l}-0.043 \\
(0.068)\end{array}$ & $\begin{array}{l}0.073 * * * \\
(0.023)\end{array}$ & $\begin{array}{l}0.074 * * * \\
(0.023)\end{array}$ & $\begin{array}{l}0.071 * * * \\
(0.023)\end{array}$ & $\begin{array}{l}-0.076 * * \\
(0.030)\end{array}$ & $\begin{array}{l}-0.076 * * \\
(0.030)\end{array}$ & $\begin{array}{l}-0.080 * * * \\
(0.029)\end{array}$ \\
\hline
\end{tabular}




\begin{tabular}{|c|c|c|c|c|c|c|c|c|c|}
\hline Year 2004 & $\begin{array}{l}-1.071 * * * \\
(0.069)\end{array}$ & $\begin{array}{l}-1.071 * * * \\
(0.069)\end{array}$ & $\begin{array}{l}-1.071 * * * \\
(0.069)\end{array}$ & $\begin{array}{l}-1.208 * * * \\
(0.056)\end{array}$ & $\begin{array}{l}-1.209 * * * \\
(0.056)\end{array}$ & $\begin{array}{l}-1.208 * * * \\
(0.056)\end{array}$ & $\begin{array}{l}-0.097 * * * \\
(0.034)\end{array}$ & $\begin{array}{l}-0.097 * * * \\
(0.034)\end{array}$ & $\begin{array}{l}-0.096 * * * \\
(0.034)\end{array}$ \\
\hline Intercept & $\begin{array}{l}7.372 * * * \\
(0.685)\end{array}$ & $\begin{array}{l}7.394 * * * \\
(0.684)\end{array}$ & $\begin{array}{l}7.265^{* * * *} \\
(0.803)\end{array}$ & $\begin{array}{l}0.675 * * \\
(0.298)\end{array}$ & $\begin{array}{l}0.654 * * \\
(0.299)\end{array}$ & $\begin{array}{l}0.601^{*} \\
(0.350)\end{array}$ & $\begin{array}{l}2.860 * * * \\
(0.262)\end{array}$ & $\begin{array}{l}2.867 * * * \\
(0.263)\end{array}$ & $\begin{array}{l}2.586 * * * \\
(0.305)\end{array}$ \\
\hline Industry effects & Yes & Yes & Yes & Yes & Yes & Yes & Yes & Yes & Yes \\
\hline Branch effects & No & No & No & No & No & No & No & No & No \\
\hline Observations & 6384 & 6384 & 6384 & 6436 & 6436 & 6436 & 6384 & 6384 & 6384 \\
\hline R2 & 0.08 & 0.08 & 0.08 & 0.17 & 0.17 & 0.17 & 0.14 & 0.14 & 0.14 \\
\hline
\end{tabular}

Note: The table presents multivariate analysis of the impact of the loan officer's gender on loan contract terms for the full sample. For the the loan officers' gender variables of relevance we utilize in all specifications the percentage of female loan officers at bank branches. Columns (1), (2), and (3) show results from OLS regressions models with dependent variable the Interest rate charged by the bank. Columns (4), (5) and (6) show results from Probit models with dependent variable Collateral which is a dichotomous variable that takes the value of 1 if the credit line is collateralized and 0 otherwise. Columns (7), (8) and (9) show the results from Probit models with dependent variable Credit availability which is a dichotomous variable that takes the value of 1 if the firm borrows more than the amount granted on the credit line by the bank and 0 if the firm exhausts its credit limit or borrows strictly less than the credit limit. The table reports point estimates of the coefficients, followed by their standard errors in parentheses, corrected for clustering at the bank-branch level. Each regression includes industry fixed effects. The definitions and construction of the variables are in the Appendix. 
TABLE 5: LOAN OfFICER GeNDER ANALYSIS - 2006 ONLY

\begin{tabular}{|c|c|c|c|c|c|c|c|c|c|}
\hline \multirow[b]{2}{*}{ Female owner } & \multicolumn{6}{|c|}{$\begin{array}{c}\text { Dependent Variables } \\
\text { Collateral }\end{array}$} & \multicolumn{3}{|c|}{ Credit Availability } \\
\hline & $\begin{array}{l}-0.080 \\
(0.094)\end{array}$ & $\begin{array}{l}-0.127 \\
(0.125)\end{array}$ & $\begin{array}{l}-0.080 \\
(0.095)\end{array}$ & $\begin{array}{l}0.206 * * * \\
(0.061)\end{array}$ & $\begin{array}{l}0.285^{* * * *} \\
(0.086)\end{array}$ & $\begin{array}{l}0.206 * * * \\
(0.061)\end{array}$ & $\begin{array}{l}0.142 * * * \\
(0.044)\end{array}$ & $\begin{array}{l}0.112 \\
(0.069)\end{array}$ & $\begin{array}{l}0.140 * * * \\
(0.043)\end{array}$ \\
\hline Relationship length & $\begin{array}{l}-0.163 * * * \\
(0.061)\end{array}$ & $\begin{array}{l}-0.163 * * * \\
(0.061)\end{array}$ & $\begin{array}{l}-0.164 * \\
(0.094)\end{array}$ & $\begin{array}{l}-0.110^{* * * *} \\
(0.025)\end{array}$ & $\begin{array}{l}-0.111 * * * \\
(0.025)\end{array}$ & $\begin{array}{l}-0.085^{* * *} \\
(0.030)\end{array}$ & $\begin{array}{l}-0.371 * * * \\
(0.030)\end{array}$ & $\begin{array}{l}-0.370^{* * *} \\
(0.030)\end{array}$ & $\begin{array}{l}-0.307 * * * \\
(0.037)\end{array}$ \\
\hline Female loan officers (in \%) & $\begin{array}{l}-0.315 \\
(0.202)\end{array}$ & & $\begin{array}{l}-0.349 \\
(-1.416)\end{array}$ & $\begin{array}{l}-0.038 \\
(0.067)\end{array}$ & & $\begin{array}{l}0.583 \\
(0.520)\end{array}$ & $\begin{array}{l}-0.112 \\
(0.098)\end{array}$ & & $\begin{array}{l}1.512 * * \\
(0.646)\end{array}$ \\
\hline Female LO x male owner & & $\begin{array}{l}-0.348^{*} \\
(0.199)\end{array}$ & & & $\begin{array}{l}0.018 \\
(0.074)\end{array}$ & & & $\begin{array}{l}-0.134 \\
(0.103)\end{array}$ & \\
\hline Female LO $\mathrm{x}$ female owner & & $\begin{array}{l}-0.194 \\
(0.303)\end{array}$ & & & $\begin{array}{l}-0.245 \\
(0.152)\end{array}$ & & & $\begin{array}{l}-0.034 \\
(0.138)\end{array}$ & \\
\hline Female $\mathrm{LO} x$ relationship length & & & $\begin{array}{l}0.004 \\
(0.177)\end{array}$ & & & $\begin{array}{l}-0.083 \\
(0.067)\end{array}$ & & & $\begin{array}{l}-0.218 * * \\
(0.086)\end{array}$ \\
\hline Firm size & $\begin{array}{l}-0.146^{*} \\
(0.084)\end{array}$ & $\begin{array}{l}-0.146^{*} \\
(0.084)\end{array}$ & $\begin{array}{l}-0.146^{*} \\
(0.084)\end{array}$ & $\begin{array}{l}0.057 \\
(0.048)\end{array}$ & $\begin{array}{l}0.058 \\
(0.047)\end{array}$ & $\begin{array}{l}0.058 \\
(0.047)\end{array}$ & $\begin{array}{l}-0.047 \\
(0.048)\end{array}$ & $\begin{array}{l}-0.048 \\
(0.048)\end{array}$ & $\begin{array}{l}-0.047 \\
(0.048)\end{array}$ \\
\hline Rationing & $\begin{array}{l}0.818^{* * *} \\
(0.104)\end{array}$ & $\begin{array}{l}0.818^{* * * *} \\
(0.104)\end{array}$ & $\begin{array}{l}0.818 * * * \\
(0.103)\end{array}$ & & & & & & \\
\hline Multiple lending & $\begin{array}{l}0.075 \\
(0.162)\end{array}$ & $\begin{array}{l}0.072 \\
(0.162)\end{array}$ & $\begin{array}{l}0.075 \\
(0.162)\end{array}$ & $\begin{array}{l}-0.574 * * * \\
(0.107)\end{array}$ & $\begin{array}{l}-0.568 * * * \\
(0.107)\end{array}$ & $\begin{array}{l}-0.573 * * * \\
(0.108)\end{array}$ & $\begin{array}{l}-0.091 \\
(0.126)\end{array}$ & $\begin{array}{l}-0.093 \\
(0.127)\end{array}$ & $\begin{array}{l}-0.087 \\
(0.128)\end{array}$ \\
\hline Other services & $\begin{array}{l}0.010 \\
(0.130)\end{array}$ & $\begin{array}{l}0.010 \\
(0.131)\end{array}$ & $\begin{array}{l}0.010 \\
(0.130)\end{array}$ & $\begin{array}{l}-0.329 * * * \\
(0.068)\end{array}$ & $\begin{array}{l}-0.330 * * * \\
(0.068)\end{array}$ & $\begin{array}{l}-0.328 * * * \\
(0.068)\end{array}$ & $\begin{array}{l}-0.932 * * * \\
(0.075)\end{array}$ & $\begin{array}{l}-0.931 * * * \\
(0.075)\end{array}$ & $\begin{array}{l}-0.931 * * * \\
(0.076)\end{array}$ \\
\hline HHI & $\begin{array}{l}-0.453 * * \\
(0.183)\end{array}$ & $\begin{array}{l}-0.457 * * \\
(0.182)\end{array}$ & $\begin{array}{l}-0.452 * * \\
(0.183)\end{array}$ & $\begin{array}{l}0.170 \\
(0.103)\end{array}$ & $\begin{array}{l}0.178^{*} \\
(0.105)\end{array}$ & $\begin{array}{l}0.159 \\
(0.103)\end{array}$ & $\begin{array}{l}-0.094 \\
(0.112)\end{array}$ & $\begin{array}{l}-0.097 \\
(0.112)\end{array}$ & $\begin{array}{l}-0.123 \\
(0.107)\end{array}$ \\
\hline Main office & $\begin{array}{l}0.379^{*} \\
(0.216)\end{array}$ & $\begin{array}{l}0.376^{*} \\
(0.217)\end{array}$ & $\begin{array}{l}0.379 * \\
(0.216)\end{array}$ & $\begin{array}{l}0.184^{*} \\
(0.095)\end{array}$ & $\begin{array}{l}0.189 * * \\
(0.095)\end{array}$ & $\begin{array}{l}0.181 * \\
(0.095)\end{array}$ & $\begin{array}{l}-0.092 \\
(0.078)\end{array}$ & $\begin{array}{l}-0.094 \\
(0.079)\end{array}$ & $\begin{array}{l}-0.103 \\
(0.079)\end{array}$ \\
\hline District branch & $\begin{array}{l}0.082 \\
(0.134)\end{array}$ & $\begin{array}{l}0.081 \\
(0.134)\end{array}$ & $\begin{array}{l}0.082 \\
(0.134)\end{array}$ & $\begin{array}{l}-0.062 \\
(0.061)\end{array}$ & $\begin{array}{l}-0.061 \\
(0.061)\end{array}$ & $\begin{array}{l}-0.065 \\
(0.061)\end{array}$ & $\begin{array}{l}0.125^{*} \\
(0.067)\end{array}$ & $\begin{array}{l}-0.126^{*} \\
(0.067)\end{array}$ & $\begin{array}{l}-0.132 * * \\
(0.067)\end{array}$ \\
\hline Branch population & $\begin{array}{l}0.002 \\
(0.003)\end{array}$ & $\begin{array}{l}0.002 \\
(0.003)\end{array}$ & $\begin{array}{l}0.002 \\
(0.003)\end{array}$ & $\begin{array}{l}-0.001 \\
(0.001)\end{array}$ & $\begin{array}{l}-0.001 \\
(0.001)\end{array}$ & $\begin{array}{l}-0.001 \\
(0.001)\end{array}$ & $\begin{array}{l}0.001 \\
(0.001)\end{array}$ & $\begin{array}{l}0.001 \\
(0.001)\end{array}$ & $\begin{array}{l}0.001 \\
(0.001)\end{array}$ \\
\hline Branch - headquarter distance & $\begin{array}{l}0.107 \\
(0.080)\end{array}$ & $\begin{array}{l}0.108 \\
(0.080)\end{array}$ & $\begin{array}{l}0.108 \\
(0.079)\end{array}$ & $\begin{array}{l}-0.075^{* * * *} \\
(0.026)\end{array}$ & $\begin{array}{l}-0.076^{* * * *} \\
(0.026)\end{array}$ & $\begin{array}{l}-0.079 * * * \\
(0.025)\end{array}$ & $\begin{array}{l}0.019 \\
(0.032)\end{array}$ & $\begin{array}{l}0.019 \\
(0.032)\end{array}$ & $\begin{array}{l}0.013 \\
(0.030)\end{array}$ \\
\hline Branch - firm distance & $\begin{array}{l}0.127 * \\
(0.065)\end{array}$ & $\begin{array}{l}0.128^{*} \\
(0.065)\end{array}$ & $\begin{array}{l}0.127 * \\
(0.064)\end{array}$ & $\begin{array}{l}-0.063 * * * \\
(0.023)\end{array}$ & $\begin{array}{l}-0.064 * * * \\
(0.023)\end{array}$ & $\begin{array}{l}-0.060 * * * \\
(0.023)\end{array}$ & $\begin{array}{l}0.053^{*} \\
(0.032)\end{array}$ & $\begin{array}{l}0.053^{*} \\
(0.032)\end{array}$ & $\begin{array}{l}0.059 * \\
(0.030)\end{array}$ \\
\hline Rivals - firm distance & $\begin{array}{l}-0.043 \\
(0.075)\end{array}$ & $\begin{array}{l}-0.043 \\
(0.075)\end{array}$ & $\begin{array}{l}-0.043 \\
(0.075)\end{array}$ & $\begin{array}{l}0.055 * * \\
(0.027)\end{array}$ & $\begin{array}{l}0.056 * * \\
(0.027)\end{array}$ & $\begin{array}{l}0.052 * \\
(0.028)\end{array}$ & $\begin{array}{l}-0.064 * * \\
(0.032)\end{array}$ & $\begin{array}{l}-0.064 * * \\
(0.032)\end{array}$ & $\begin{array}{l}-0.071 * * \\
(0.031)\end{array}$ \\
\hline Intercept & $\begin{array}{l}7.637 * * * \\
(0.702)\end{array}$ & $\begin{array}{l}7.649 * * * \\
(0.699)\end{array}$ & $\begin{array}{l}7.646 * * * \\
(0.854)\end{array}$ & $\begin{array}{l}1.582 * * * \\
(0.311)\end{array}$ & $\begin{array}{l}1.562 * * * \\
(0.312)\end{array}$ & $\begin{array}{l}1.408 * * * \\
(0.351)\end{array}$ & $\begin{array}{l}3.492 * * * \\
(0.323)\end{array}$ & $\begin{array}{l}3.500 * * * \\
(0.325)\end{array}$ & $\begin{array}{l}3.051 * * * \\
(0.424)\end{array}$ \\
\hline
\end{tabular}


Industry effects

Branch effects

Observations

R2

No

3705

0.06

Yes
No
3705
0.06

0.06

\section{Yes \\ No \\ 3705}

Yes
No
3703

3703
0.05
Yes
No
3703

0.05

Yes
No
3703
0.05

Note: The table presents multivariate analysis of the impact of the loan officer's gender on loan contract terms using the sub-sample of observations in year 2006 only. For the loan officer's gender variables of relevance we utilize in all specifications the percentage of female loan officers at bank branches. Columns (1), (2), and (3) show results from OLS regression models with dependent variable the Interest rate charged by the bank. Columns (4), (5) and (6) show results from Probit models with dependent variable Collateral which is a dichotomous variable that takes the value of 1 if the credit line is collateralized and 0 otherwise. Columns (7), (8) and (9) show the results from Probit models with dependent variable Credit availability which is a dichotomous variable that takes the value of 1 if the firm borrows more than the amount granted on the credit line by the bank and 0 if the firm exhausts its credit limit or borrows strictly less than the credit limit. The table reports point estimates of the coefficients, followed by their standard errors in parentheses, corrected for clustering at the bank-branch level. Each regression includes industry fixed effects. The definitions and construction of the variables are in the Appendix. 
TAble 6: LoAn Officer Gender ANAlysis - Mono-gender BrancheS - Full SAMPLE

\begin{tabular}{|c|c|c|c|c|c|c|c|c|c|}
\hline \multirow[b]{2}{*}{ Female owner } & \multicolumn{9}{|c|}{ Dependent Variables } \\
\hline & $\begin{array}{l}-0.070 \\
(0.153)\end{array}$ & $\begin{array}{l}-0.130 \\
(0.165)\end{array}$ & $\begin{array}{l}-0.069 \\
(0.153)\end{array}$ & $\begin{array}{l}0.132 * \\
(0.076)\end{array}$ & $\begin{array}{l}0.198 * * \\
(0.082)\end{array}$ & $\begin{array}{l}0.132 * \\
(0.076)\end{array}$ & $\begin{array}{l}0.119 * \\
(0.066)\end{array}$ & $\begin{array}{l}0.117 \\
(0.071)\end{array}$ & $\begin{array}{l}0.120^{*} \\
(0.066)\end{array}$ \\
\hline Relationship length & $\begin{array}{l}-0.093 \\
(0.079)\end{array}$ & $\begin{array}{l}-0.092 \\
(0.079)\end{array}$ & $\begin{array}{l}-0.085 \\
(0.092)\end{array}$ & $\begin{array}{l}-0.025 \\
(0.025)\end{array}$ & $\begin{array}{l}-0.025 \\
(0.025)\end{array}$ & $\begin{array}{l}-0.029 \\
(0.023)\end{array}$ & $\begin{array}{l}-0.275^{* * * *} \\
(0.027)\end{array}$ & $\begin{array}{l}-0.275^{* * *} \\
(0.027)\end{array}$ & $\begin{array}{l}-0.264 * * * \\
(0.030)\end{array}$ \\
\hline Only Female loan officers & $\begin{array}{l}-0.119 \\
(0.158)\end{array}$ & & $\begin{array}{l}0.290 \\
(0.805)\end{array}$ & $\begin{array}{l}0.023 \\
(0.053)\end{array}$ & & $\begin{array}{l}-0.179 \\
(0.686)\end{array}$ & $\begin{array}{l}0.023 \\
(0.059)\end{array}$ & & $\begin{array}{l}0.594 * \\
(0.347)\end{array}$ \\
\hline Only female LO x male owner & & $\begin{array}{l}-0.210 \\
(0.161)\end{array}$ & & & $\begin{array}{l}0.121 \\
(0.075)\end{array}$ & & & $\begin{array}{l}0.020 \\
(0.068)\end{array}$ & \\
\hline Only female LO $\mathrm{x}$ female owner & & $\begin{array}{l}0.224 \\
(0.222)\end{array}$ & & & $\begin{array}{l}-0.376 * * \\
(0.191)\end{array}$ & & & $\begin{array}{l}0.035 \\
(0.092)\end{array}$ & \\
\hline Only female LO $\mathrm{x}$ relationship length & & & $\begin{array}{l}-0.055 \\
(0.102)\end{array}$ & & & $\begin{array}{l}0.027 \\
(0.091)\end{array}$ & & & $\begin{array}{l}-0.076^{*} \\
(0.046)\end{array}$ \\
\hline Firm size & $\begin{array}{l}-0.051 \\
(0.123)\end{array}$ & $\begin{array}{l}-0.054 \\
(0.122)\end{array}$ & $\begin{array}{l}-0.051 \\
(0.124)\end{array}$ & $\begin{array}{l}0.238 * * * \\
(0.057)\end{array}$ & $\begin{array}{l}0.241 * * * \\
(0.057)\end{array}$ & $\begin{array}{l}0.238 * * * \\
(0.057)\end{array}$ & $\begin{array}{l}-0.117 * * \\
(0.050)\end{array}$ & $\begin{array}{l}-0.118^{* *} \\
(0.050)\end{array}$ & $\begin{array}{c}-0.118 * * \\
(0.050)\end{array}$ \\
\hline Rationing & $\begin{array}{l}0.698 * * * \\
(0.126)\end{array}$ & $\begin{array}{l}0.698 * * * \\
(0.127)\end{array}$ & $\begin{array}{l}0.697 * * * \\
(0.126)\end{array}$ & & & & & & \\
\hline Multiple lending & $\begin{array}{l}0.468^{*} \\
(0.239)\end{array}$ & $\begin{array}{l}0.459 * \\
(0.238)\end{array}$ & $\begin{array}{l}0.469 * \\
(0.239)\end{array}$ & $\begin{array}{l}-0.420 * * * \\
(0.137)\end{array}$ & $\begin{array}{l}-0.413 * * * \\
(0.138)\end{array}$ & $\begin{array}{l}-0.421 * * * \\
(0.138)\end{array}$ & $\begin{array}{l}-0.392 * * \\
(0.158)\end{array}$ & $\begin{array}{l}-0.392 * * \\
(0.158)\end{array}$ & $\begin{array}{l}-0.391 * * \\
(0.159)\end{array}$ \\
\hline Other services & $\begin{array}{l}0.118 \\
(0.173)\end{array}$ & $\begin{array}{l}0.119 \\
(0.172)\end{array}$ & $\begin{array}{l}0.119 \\
(0.173)\end{array}$ & $\begin{array}{l}-0.248 * * * \\
(0.087)\end{array}$ & $\begin{array}{l}-0.251 * * * \\
(0.086)\end{array}$ & $\begin{array}{l}-0.250 * * * \\
(0.087)\end{array}$ & $\begin{array}{l}-0.856 * * * \\
(0.084)\end{array}$ & $\begin{array}{l}-0.856 * * * \\
(0.084)\end{array}$ & $\begin{array}{l}-0.855^{* * *} \\
(0.084)\end{array}$ \\
\hline HHI & $\begin{array}{l}-0.393^{*} \\
(0.226)\end{array}$ & $\begin{array}{l}-0.399^{*} \\
(0.226)\end{array}$ & $\begin{array}{l}-0.397^{*} \\
(0.226)\end{array}$ & $\begin{array}{l}0.084 \\
(0.103)\end{array}$ & $\begin{array}{l}0.090 \\
(0.105)\end{array}$ & $\begin{array}{l}0.086 \\
(0.103)\end{array}$ & $\begin{array}{l}-0.321 * * * \\
(0.112)\end{array}$ & $\begin{array}{l}-0.322 * * * \\
(0.112)\end{array}$ & $\begin{array}{l}-0.325^{* * *} \\
(0.111)\end{array}$ \\
\hline District branch & $\begin{array}{l}0.058 \\
(0.188)\end{array}$ & $\begin{array}{l}0.055 \\
(0.188)\end{array}$ & $\begin{array}{l}0.056 \\
(0.188)\end{array}$ & $\begin{array}{l}0.052 \\
(0.050)\end{array}$ & $\begin{array}{l}0.055 \\
(0.050)\end{array}$ & $\begin{array}{l}0.052 \\
(0.050)\end{array}$ & $\begin{array}{l}-0.106^{*} \\
(0.062)\end{array}$ & $\begin{array}{l}-0.106^{*} \\
(0.062)\end{array}$ & $\begin{array}{l}-0.108^{*} \\
(0.062)\end{array}$ \\
\hline Branch population & $\begin{array}{l}0.005 \\
(0.004)\end{array}$ & $\begin{array}{l}0.006 \\
(0.004)\end{array}$ & $\begin{array}{l}0.005 \\
(0.004)\end{array}$ & $\begin{array}{l}-0.001 \\
(0.001)\end{array}$ & $\begin{array}{l}-0.001 \\
(0.001)\end{array}$ & $\begin{array}{l}-0.001 \\
(0.001)\end{array}$ & $\begin{array}{l}0.001 \\
(0.001)\end{array}$ & $\begin{array}{l}0.001 \\
(0.001)\end{array}$ & $\begin{array}{l}0.001 \\
(0.001)\end{array}$ \\
\hline Branch - headquarter distance & $\begin{array}{l}0.214 * * * \\
(0.064)\end{array}$ & $\begin{array}{l}0.215 * * * \\
(0.064)\end{array}$ & $\begin{array}{l}0.212 * * * \\
(0.064)\end{array}$ & $\begin{array}{l}-0.070 * * * \\
(0.023)\end{array}$ & $\begin{array}{l}-0.072 * * * \\
(0.023)\end{array}$ & $\begin{array}{l}-0.069 * * * \\
(0.023)\end{array}$ & $\begin{array}{l}0.023 \\
(0.027)\end{array}$ & $\begin{array}{l}0.023 \\
(0.027)\end{array}$ & $\begin{array}{l}0.022 \\
(0.027)\end{array}$ \\
\hline Branch - firm distance & $\begin{array}{l}0.066 \\
(0.072)\end{array}$ & $\begin{array}{l}0.067 \\
(0.072)\end{array}$ & $\begin{array}{l}0.067 \\
(0.072)\end{array}$ & $\begin{array}{l}-0.063 * * * \\
(0.023)\end{array}$ & $\begin{array}{l}-0.063 * * * \\
(0.023)\end{array}$ & $\begin{array}{l}-0.064 * * \\
(0.023)\end{array}$ & $\begin{array}{l}0.078 * * \\
(0.032)\end{array}$ & $\begin{array}{l}0.078 * * \\
(0.032)\end{array}$ & $\begin{array}{l}0.079 * * \\
(0.031)\end{array}$ \\
\hline Rivals - firm distance & $\begin{array}{l}0.033 \\
(0.074)\end{array}$ & $\begin{array}{l}0.032 \\
(0.074)\end{array}$ & $\begin{array}{l}0.031 \\
(0.074)\end{array}$ & $\begin{array}{l}0.056 * * \\
(0.027)\end{array}$ & $\begin{array}{l}0.058 * * \\
(0.027)\end{array}$ & $\begin{array}{l}0.057 * * \\
(0.026)\end{array}$ & $\begin{array}{l}-0.097 * * * \\
(0.031)\end{array}$ & $\begin{array}{l}-0.097 * * * \\
(0.031)\end{array}$ & $\begin{array}{l}-0.098 * * * \\
(0.031)\end{array}$ \\
\hline Year 2004 & $\begin{array}{l}-1.094 * * * \\
(0.084)\end{array}$ & $\begin{array}{l}-1.095^{* * *} \\
(0.084)\end{array}$ & $\begin{array}{l}-1.095^{* * *} \\
(0.084)\end{array}$ & $\begin{array}{l}-1.243^{* * *} \\
(0.089)\end{array}$ & $\begin{array}{l}-1.244 * * * \\
(0.089)\end{array}$ & $\begin{array}{l}-1.242 * * * \\
(0.089)\end{array}$ & $\begin{array}{l}-0.098 * * \\
(0.046)\end{array}$ & $\begin{array}{l}-0.098^{* *} \\
(0.046)\end{array}$ & $\begin{array}{l}-0.099 * * \\
(0.045)\end{array}$ \\
\hline Intercept & $\begin{array}{l}5.882 * * * \\
(1.054)\end{array}$ & $\begin{array}{l}5.908 * * * \\
(1.055)\end{array}$ & $\begin{array}{l}5.832 * * * \\
(1.100)\end{array}$ & $\begin{array}{l}0.999 * * \\
(0.438)\end{array}$ & $\begin{array}{l}0.972^{* *} \\
(0.440)\end{array}$ & $\begin{array}{l}1.024 * * \\
(0.464)\end{array}$ & $\begin{array}{l}3.164 * * * \\
(0.355)\end{array}$ & $\begin{array}{l}3.165 * * * \\
(0.355)\end{array}$ & $\begin{array}{l}3.099 * * * \\
(0.354)\end{array}$ \\
\hline
\end{tabular}




\begin{tabular}{|c|c|c|c|c|c|c|c|c|c|}
\hline Industry effects & Yes & Yes & Yes & Yes & Yes & Yes & Yes & Yes & Yes \\
\hline Branch effects & No & No & No & No & No & No & No & No & No \\
\hline Observations & 3600 & 3600 & 3600 & 3629 & 3629 & 3629 & 3600 & 3600 & 3600 \\
\hline R2 & 0.10 & 0.10 & 0.10 & 0.17 & 0.17 & 0.17 & 0.12 & 0.12 & 0.12 \\
\hline
\end{tabular}

Note: The table presents multivariate analysis of the impact of the loan officer's gender on loan contract terms for the full sample using credit lines originated at bank branches populated by only male or only female loan officers. For the loan officer's gender variables of relevance we utilize Only female loan officers which takes the value of 1 if all loan officers at the bank branch are females and 0 if all loan officers at the bank branch are males. Columns (1), (2), and (3) show results from OLS regression models with dependent variable the Interest rate charged by the bank. Columns (4), (5) and (6) show results from Probit models with dependent variable Collateral which is a dichotomous variable that takes the value of 1 if the credit line is collateralized and 0 otherwise. Columns (7), (8) and (9) show the results from Probit models with dependent variable Credit availability which is a dichotomous variable that takes the value of 1 if the firm's borrowing exceeds the amount granted on the credit line by the bank and 0 if the firm exhausts its credit limit or borrows strictly less than the credit limit. The table reports point estimates of the coefficients, followed by their standard errors in parentheses, corrected for clustering at the bank-branch level. Each regression includes industry fixed effects. The definitions and construction of the variables are in the Appendix. 
TABle 7: LoAn OfFICER Gender ANALYSIS - MONO-GENDER BRANCHES - 2006 ONLY

\begin{tabular}{|c|c|c|c|c|c|c|c|c|c|}
\hline \multirow[b]{3}{*}{ Female owner } & \multicolumn{9}{|c|}{ Dependent Variables } \\
\hline & \multicolumn{3}{|c|}{ Interest rate } & \multicolumn{3}{|c|}{ Collateral } & \multicolumn{3}{|c|}{ Credit Availability } \\
\hline & $\begin{array}{l}-0.086 \\
(0.129)\end{array}$ & $\begin{array}{l}-0.139 \\
(0.144)\end{array}$ & $\begin{array}{l}-0.087 \\
(0.127)\end{array}$ & $\begin{array}{l}0.179 * * \\
(0.083)\end{array}$ & $\begin{array}{l}0.235 * * * \\
(0.089)\end{array}$ & $\begin{array}{l}0.180 * * \\
(0.082)\end{array}$ & $\begin{array}{l}0.142 * \\
(0.074)\end{array}$ & $\begin{array}{l}0.132 \\
(0.081)\end{array}$ & $\begin{array}{l}0.143 * \\
(0.074)\end{array}$ \\
\hline Relationship length & $\begin{array}{l}-0.161 * \\
(0.095)\end{array}$ & $\begin{array}{l}-0.161^{*} \\
(0.095)\end{array}$ & $\begin{array}{l}-0.164 \\
(0.108)\end{array}$ & $\begin{array}{l}-0.101 * * * * \\
(0.030)\end{array}$ & $\begin{array}{l}-0.101 * * * \\
(0.030)\end{array}$ & $\begin{array}{l}-0.094 * * * \\
(0.031)\end{array}$ & $\begin{array}{l}-0.314 * * * \\
(0.039)\end{array}$ & $\begin{array}{l}-0.314 * * * \\
(0.039)\end{array}$ & $\begin{array}{l}-0.301 * * * \\
(0.043)\end{array}$ \\
\hline Only female loan officers & $\begin{array}{l}-0.223 \\
(0.189)\end{array}$ & & $\begin{array}{l}-0.425 \\
(1.023)\end{array}$ & $\begin{array}{c}-0.011 \\
(0.060)\end{array}$ & & $\begin{array}{l}0.399 \\
(0.689)\end{array}$ & $\begin{array}{l}-0.007 \\
(0.084)\end{array}$ & & $\begin{array}{l}0.872 * \\
(0.451)\end{array}$ \\
\hline Only female LO x Male owner & & $\begin{array}{l}-0.303 \\
(0.188)\end{array}$ & & & $\begin{array}{l}0.075 \\
(0.073)\end{array}$ & & & $\begin{array}{l}-0.023 \\
(0.088)\end{array}$ & \\
\hline Only female LO x Female owner & & $\begin{array}{l}0.097 \\
(0.240)\end{array}$ & & & $\begin{array}{l}-0.356 \\
(0.234)\end{array}$ & & & $\begin{array}{l}0.053 \\
(0.102)\end{array}$ & \\
\hline Only Female LO x Relationship length & & & $\begin{array}{l}0.027 \\
(0.130)\end{array}$ & & & $\begin{array}{l}-0.055 \\
(0.089)\end{array}$ & & & $\begin{array}{l}-0.117^{*} \\
(0.061)\end{array}$ \\
\hline Firm size & $\begin{array}{l}-0.117 \\
(0.111)\end{array}$ & $\begin{array}{l}-0.119 \\
(0.110)\end{array}$ & $\begin{array}{l}-0.117 \\
(0.112)\end{array}$ & $\begin{array}{l}0.108 \\
(0.072)\end{array}$ & $\begin{array}{l}0.110 \\
(0.072)\end{array}$ & $\begin{array}{l}0.109 \\
(0.072)\end{array}$ & $\begin{array}{l}-0.115^{*} \\
(0.060)\end{array}$ & $\begin{array}{l}-0.115^{*} \\
(0.060)\end{array}$ & $\begin{array}{r}-0.115^{*} \\
(0.060)\end{array}$ \\
\hline Rationing & $\begin{array}{l}0.766 * * * \\
(0.151)\end{array}$ & $\begin{array}{l}0.765 * * * \\
(0.151)\end{array}$ & $\begin{array}{l}0.766 * * * \\
(0.151)\end{array}$ & & & & & & \\
\hline Multiple lending & $\begin{array}{l}0.425 * \\
(0.241)\end{array}$ & $\begin{array}{l}0.416^{*} \\
(0.241)\end{array}$ & $\begin{array}{l}0.424 * \\
(0.242)\end{array}$ & $\begin{array}{l}-0.739 * * * \\
(0.147)\end{array}$ & $\begin{array}{l}-0.730 * * * \\
(0.148)\end{array}$ & $\begin{array}{l}-0.738 * * * \\
(0.147)\end{array}$ & $\begin{array}{l}-0.436 * * * \\
(0.163)\end{array}$ & $\begin{array}{l}-0.438 * * * \\
(0.163)\end{array}$ & $\begin{array}{l}-0.436 * * * \\
(0.164)\end{array}$ \\
\hline Other services & $\begin{array}{l}0.031 \\
(0.155)\end{array}$ & $\begin{array}{l}0.030 \\
(0.155)\end{array}$ & $\begin{array}{l}0.030 \\
(0.155)\end{array}$ & $\begin{array}{l}-0.259^{* * *} \\
(0.096)\end{array}$ & $\begin{array}{l}-0.258 * * * \\
(0.095)\end{array}$ & $\begin{array}{l}-0.257 * * * \\
(0.097)\end{array}$ & $\begin{array}{l}-0.834 * * * \\
(0.099)\end{array}$ & $\begin{array}{l}-0.834 * * * \\
(0.099)\end{array}$ & $\begin{array}{l}-0.831 * * * \\
(0.099)\end{array}$ \\
\hline HHI & $\begin{array}{l}-0.422 * \\
(0.217)\end{array}$ & $\begin{array}{l}-0.428^{*} \\
(0.216)\end{array}$ & $\begin{array}{l}-0.420^{*} \\
(0.218)\end{array}$ & $\begin{array}{l}0.120 \\
(0.108)\end{array}$ & $\begin{array}{l}0.126 \\
(0.110)\end{array}$ & $\begin{array}{l}0.116 \\
(0.108)\end{array}$ & $\begin{array}{l}-0.352 * * * \\
(0.110)\end{array}$ & $\begin{array}{l}-0.352 * * * \\
(0.110)\end{array}$ & $\begin{array}{l}-0.360^{* * *} \\
(0.110)\end{array}$ \\
\hline District branch & $\begin{array}{l}0.119 \\
(0.193)\end{array}$ & $\begin{array}{c}0.117 \\
(0.193)\end{array}$ & $\begin{array}{l}0.120 \\
(0.193)\end{array}$ & $\begin{array}{l}-0.027 \\
(0.064)\end{array}$ & $\begin{array}{l}-0.025 \\
(0.064)\end{array}$ & $\begin{array}{l}-0.028 \\
(0.064)\end{array}$ & $\begin{array}{l}-0.126 \\
(0.089)\end{array}$ & $\begin{array}{l}-0.126 \\
(0.089)\end{array}$ & $\begin{array}{l}-0.127 \\
(0.089)\end{array}$ \\
\hline Branch population & $\begin{array}{l}0.007 \\
(0.004)\end{array}$ & $\begin{array}{l}0.007 \\
(0.004)\end{array}$ & $\begin{array}{l}0.007 \\
(0.004)\end{array}$ & $\begin{array}{l}-0.002 * \\
(0.001)\end{array}$ & $\begin{array}{l}-0.002 * \\
(0.001)\end{array}$ & $\begin{array}{l}-0.002 * \\
(0.001)\end{array}$ & $\begin{array}{l}0.001 \\
(0.002)\end{array}$ & $\begin{array}{l}0.001 \\
(0.002)\end{array}$ & $\begin{array}{l}0.000 \\
(0.002)\end{array}$ \\
\hline Branch - headquarter distance & $\begin{array}{l}0.216^{* * * *} \\
(0.077)\end{array}$ & $\begin{array}{l}0.218 * * * \\
(0.077)\end{array}$ & $\begin{array}{l}0.217 * * * \\
(0.077)\end{array}$ & $\begin{array}{l}-0.089 * * * * \\
(0.027)\end{array}$ & $\begin{array}{l}-0.091 * * * \\
(0.027)\end{array}$ & $\begin{array}{l}-0.091 * * * \\
(0.027)\end{array}$ & $\begin{array}{l}0.034 \\
(0.036)\end{array}$ & $\begin{array}{l}0.035 \\
(0.036)\end{array}$ & $\begin{array}{l}0.033 \\
(0.036)\end{array}$ \\
\hline Branch - firm distance & $\begin{array}{l}0.102 \\
(0.082)\end{array}$ & $\begin{array}{l}0.102 \\
(0.082)\end{array}$ & $\begin{array}{l}0.101 \\
(0.082)\end{array}$ & $\begin{array}{l}-0.041 \\
(0.027)\end{array}$ & $\begin{array}{l}-0.041 \\
(0.027)\end{array}$ & $\begin{array}{l}-0.040 \\
(0.027)\end{array}$ & $\begin{array}{l}0.092 * * \\
(0.038)\end{array}$ & $\begin{array}{l}0.092 * * \\
(0.038)\end{array}$ & $\begin{array}{l}0.093 * * \\
(0.037)\end{array}$ \\
\hline Rivals - firm distance & $\begin{array}{l}0.036 \\
(0.079)\end{array}$ & $\begin{array}{l}0.035 \\
(0.079)\end{array}$ & $\begin{array}{l}0.037 \\
(0.079)\end{array}$ & $\begin{array}{l}0.045 \\
(0.033)\end{array}$ & $\begin{array}{l}0.046 \\
(0.033)\end{array}$ & $\begin{array}{l}0.043 \\
(0.033)\end{array}$ & $\begin{array}{l}-0.080 * * \\
(0.034)\end{array}$ & $\begin{array}{l}-0.080 * * \\
(0.034)\end{array}$ & $\begin{array}{l}-0.082^{* *} \\
(0.035)\end{array}$ \\
\hline Intercept & $\begin{array}{l}5.954 * * * \\
(0.965)\end{array}$ & $\begin{array}{l}5.981^{* * * *} \\
(0.966)\end{array}$ & $\begin{array}{l}5.978 * * * \\
(1.020)\end{array}$ & $\begin{array}{l}2.103 * * * \\
(0.494)\end{array}$ & $\begin{array}{l}2.076^{* * * *} \\
(0.495)\end{array}$ & $\begin{array}{l}2.053 * * * \\
(0.504)\end{array}$ & $\begin{array}{l}3.707 * * * \\
(0.529)\end{array}$ & $\begin{array}{l}3.712 * * * \\
(0.530)\end{array}$ & $\begin{array}{l}3.609 * * * \\
(0.538)\end{array}$ \\
\hline Industry Effects & Yes & Yes & Yes & Yes & Yes & Yes & Yes & Yes & Yes \\
\hline Branch Effects & No & No & No & No & No & No & No & No & No \\
\hline
\end{tabular}


Note: The table presents multivariate analysis of the impact of the loan officer's gender on loan contract terms using the subsample of year 2006 credit lines originated at bank branches populated by only male or only female loan officers. For the loan officer's gender variables of relevance we utilize Only female loan officers which takes the value of 1 if all loan officers at the bank branch are females and 0 if all loan officers at the bank branch are males. Columns (1), (2), and (3) show results from OLS regression models with dependent variable the Interest rate charged by the bank. Columns (4), (5) and (6) show results from Probit models with dependent variable Collateral which is a dichotomous variable that takes the value of 1 if the credit line is collateralized and 0 otherwise. Columns (7), (8) and (9) show the results from Probit models with dependent variable Credit availability which is a dichotomous variable that takes the value of 1 if the firm's borrowing exceeds the amount granted on the credit line by the bank and 0 if the firm exhausts its credit limit or borrows strictly less than the credit limit. The table reports point estimates of the coefficients, followed by their standard errors in parentheses, corrected for clustering at the bank-branch level. Each regression includes industry fixed effects. The definitions and construction of the variables are in the Appendix. 
Figure 1: MARginal IMPACt Of LoAn OfFicer Gender on COLlateral REQUiREMENTS - Full SAMPLe

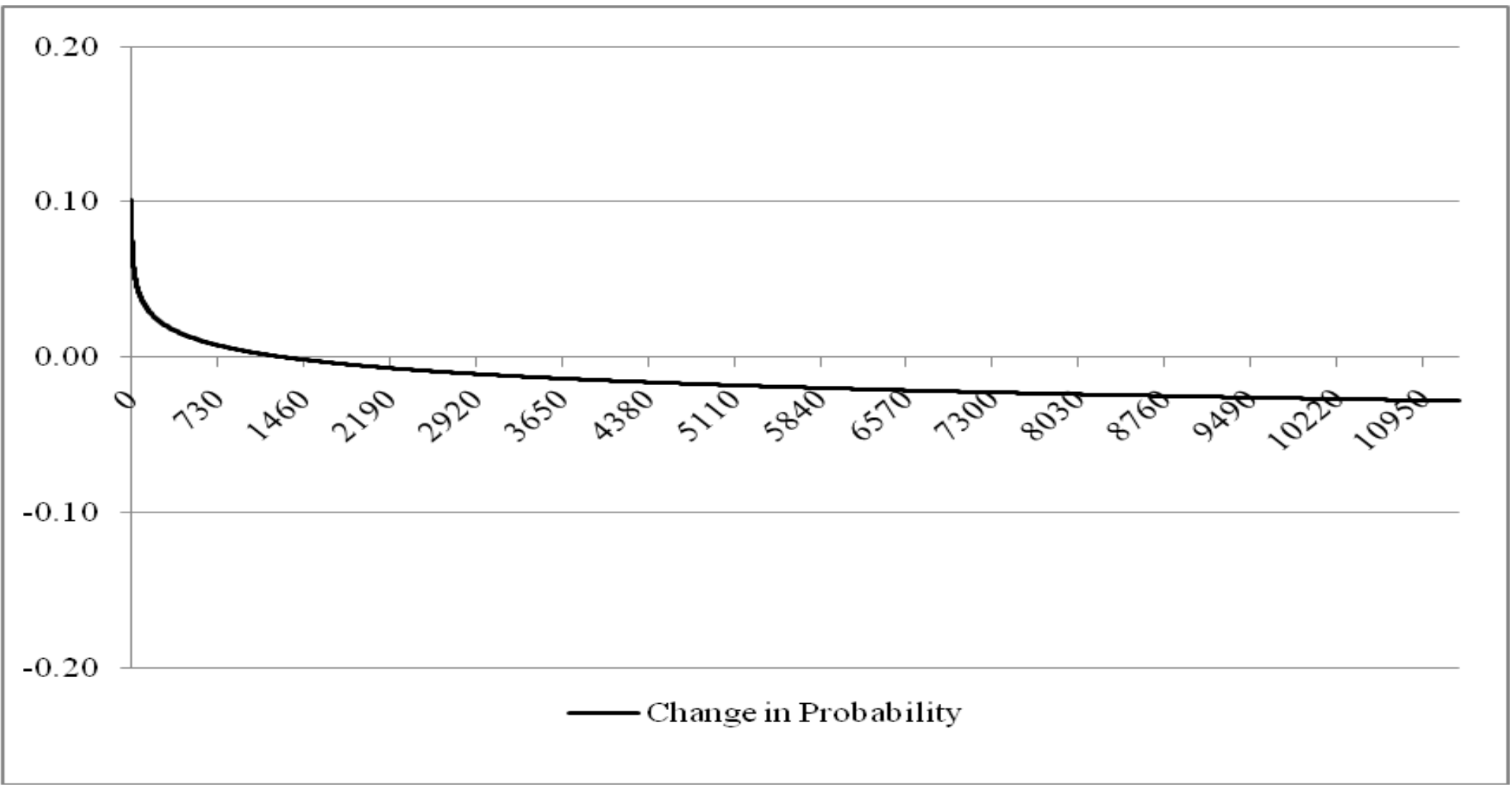

Note: The figure shows the impact of the loan officer's gender on the probability that the bank will require collateral. Specifically, we allow the variable Relationship length to vary between 0 and its maximum of 11,251 days. Using the coefficients estimated in Column (6) of Table 4, we predict the incidence of collateral, at each possible realization of Relationship length, when Female loan officers takes the value of 0 and the value of 1 . The difference between these two probabilities is computed at each value of Relationship length. The series of these differences is plotted on the graph. 
Figure 2: MARginal IMPaCt OF LoAN OfFicer Gender ON Credit Availability - Full SaMPle

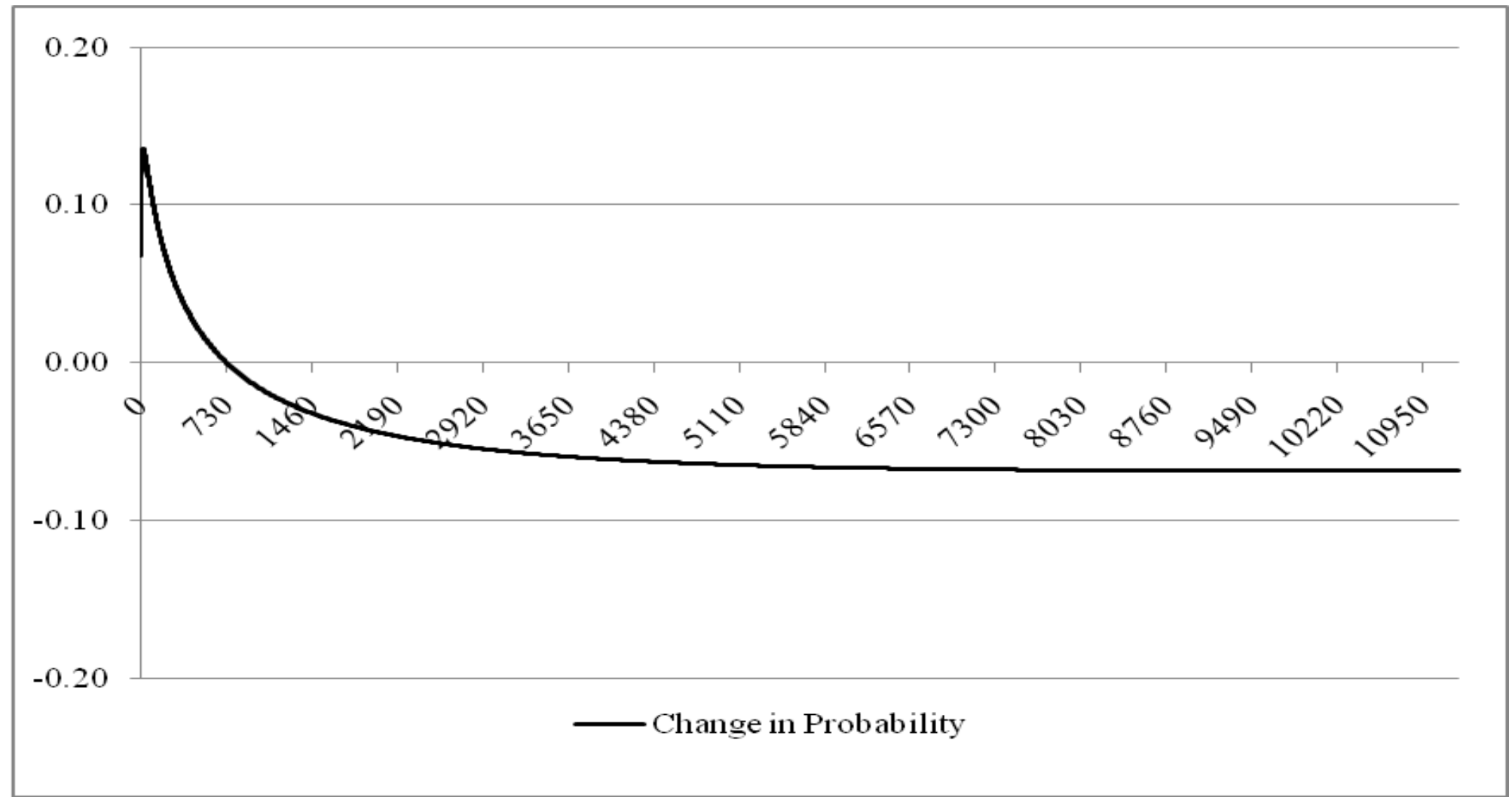

Note: The figure shows the impact of the loan officer's gender on the probability that a borrower overdraws funds from the credit line. Specifically, we allow the variable Relationship length to vary between 0 and its maximum of 11,251 days. All other variables are kept at their median values. Using the coefficients estimated in Column (9) of Table 4, we predict the incidence of overdrawing, at each possible realization of Relationship length, when Female loan officers takes the value of 0 and when it takes the value of 1 . The difference between these two probabilities is computed at each value of Relationship length. The series of these differences is plotted in the graph. 


\section{Appendix: List of Variables}

\begin{tabular}{|c|c|}
\hline VARIABLE & DEFINITION \\
\hline Interest rate & The interest rate charged by the bank, expressed as a percentage \\
\hline Collateral & $\begin{array}{l}\text { A dichotomous variable that take the value of } 1 \text { if the credit line is } \\
\text { secured by a real guarantee and } 0 \text { otherwise. }\end{array}$ \\
\hline Credit availability & $\begin{array}{l}\text { A dichotomous variable that takes the value of } 1 \text { if the borrower } \\
\text { uses more or exhausts the amount granted on the credit line by the } \\
\text { bank and } 0 \text { otherwise. }\end{array}$ \\
\hline Female owner & $\begin{array}{l}\text { A dichotomous variable that takes the value of } 1 \text { if the owner of the } \\
\text { firm is female and } 0 \text { if the owner of the firm is male. }\end{array}$ \\
\hline Female loan officers (in \%) & $\begin{array}{l}\text { A continuous variable that measures the percent of female loan } \\
\text { officers with decision-making power at the bank branch: } \\
\text { constructed as the ratio of female loan officers to the total number } \\
\text { of loan officers at the bank branch. Bounded between } 0 \text { and } 1 .\end{array}$ \\
\hline Only female loan officer & $\begin{array}{l}\text { A dichotomous variable that takes the value of } 1 \text { if all loan officers } \\
\text { at the bank branch are females and } 0 \text { if all loan officers at the bank } \\
\text { branch are males. Used in the subsample of loan contracts } \\
\text { originating from bank branches where all loan officers are either } \\
\text { male or female. At the bank branches there are only female loan } \\
\text { officers, } 0 \text { otherwise. }\end{array}$ \\
\hline Firm size & $\begin{array}{l}\text { A step variable that takes the value of: } 1 \text { if the borrower's total } \\
\text { sales are less than } € 250,000 ; 2 \text { if the borrower's total sales are } \\
\text { between } € 250,000 \text { and } € 1,500,000 \text {; and } 3 \text { if the borrower's total } \\
\text { sales exceed } € 1,500,000 \text {. }\end{array}$ \\
\hline Multiple lending & $\begin{array}{l}\text { A dichotomous variable that takes the value of } 1 \text { if the borrower } \\
\text { has multiple bank-borrower relationships and } 0 \text { if the borrower has } \\
\text { an exclusive relationship with this bank. }\end{array}$ \\
\hline Other services & $\begin{array}{l}\text { A dichotomous variable that takes the value of } 1 \text { if the bank branch } \\
\text { provides other (besides the credit line) services to the borrower and } \\
0 \text { otherwise. }\end{array}$ \\
\hline Relationship length $(\ln (1+$ Days $))$ & $\begin{array}{l}\text { A continuous variable that measures the length of the bank- } \\
\text { borrower relationship: constructed as the natural logarithm of } 1+ \\
\text { the length of the bank-borrower relationship expressed in days. }\end{array}$ \\
\hline Main office & $\begin{array}{l}\text { A dichotomous variable that takes the value of } 1 \text { if the bank branch } \\
\text { is the local headquarters of the bank and } 0 \text { otherwise. }\end{array}$ \\
\hline District branch & $\begin{array}{l}\text { A dichotomous variable that takes the value of } 1 \text { if the bank branch } \\
\text { is located within an industrial cluster area and } 0 \text { otherwise. }\end{array}$ \\
\hline Branch - headquarter distance & $\begin{array}{l}\text { Natural logarithm of the distance in } \mathrm{km} \text { between the bank branch } \\
\text { and the bank's headquarters }\end{array}$ \\
\hline Branch - firm distance & $\begin{array}{l}\text { Natural logarithm of the distance in } \mathrm{km} \text { between the firm and its } \\
\text { lending bank branch. }\end{array}$ \\
\hline Rivals - firm distance & $\begin{array}{l}\text { Natural logarithm of } 25^{\text {th }} \text { percentile of distances in } \mathrm{km} \text { between the } \\
\text { firm and bank branches of competing banks in the local credit } \\
\text { market. }\end{array}$ \\
\hline HHI (Bank Branch) & $\begin{array}{l}\text { A branch-based Herfindahl-Hirschman Index of market } \\
\text { concentration. The relevant market for each bank branch is } \\
\text { determined by the postal area code where the branch is located. }\end{array}$ \\
\hline Branch population & $\begin{array}{l}\text { Population (in thousand) in the local credit market defined by the } \\
\text { postal area code where the bank branch is located. }\end{array}$ \\
\hline
\end{tabular}

